\title{
LE RATTACHEMENT D'UN PEUPLE MARRON A LA FRANCE - LES BONI, DE LA GUYANE NEERLANDAISE A LA GUYANE FRANÇAISE $1836-1892^{1}$
}

\author{
O VÍNCULO DE UM POVO MARROM COM A FRANÇA, OS BONIS, DA GUIANA \\ HOLANDESA Aे GUIANA FRANCESA 1836-1892
}

Yerri Urban ${ }^{2}$

\begin{abstract}
Résumé : Les Boni sont aujourd'hui regardés comme le seul peuple marron rattaché à la France. L'article retrace les étapes qui ont abouti à cette situation. Massacrés par les Marrons Ndjuka, alliés des Néerlandais, en 1793, les Boni ne concluent pas de traité de paix avec les Pays-Bas par la suite : ils sont placés sous une sorte de «tutelle » des Ndjuka reconnue tant par les Néerlandais que par les Français. En 1860, avec les abolitions de l'esclavage, les Boni se voient reconnaître leur liberté par les deux puissances coloniales. Progressivement, à partir de 1880 et en raison d'un litige frontalier entre la France et les Pays-Bas, les Boni nouent un lien avec la France, confirmé en 1892.

Mots-clefs: Peuples marrons; Esclavage; Guyanes française et néerlandaise; Droit colonial; Droit international public.

Resumo : Os Bonis são hoje considerados os únicos "povos marrons" vinculados à França. O artigo rastreia as etapas que levaram a essa situação. Massacrados, em 1793, pelos "marrons" de Ndjuka, aliados dos holandeses, os Bonis não concluíram um tratado de paz com os Países Baixos, na ocasião: eles foram colocados sob uma espécie de «tutela» dos Ndjuka, reconhecida tanto pelos holandeses quanto pelos franceses. Em 1860, com a abolição da escravidão, os Bonis tiveram sua liberdade reconhecida pelas duas potências coloniais. Progressivamente, a partir de 1880 e em razão de um litígio de fronteira entre a França e os Países Baixos, os Bonis estabeleceram um laço com a França, confirmado em 1892.
\end{abstract}

Palavras-chave: Povos "marrons"; Escravidão; Guiana Francesa e Holandesa; Direito colonial; Direito internacional público

Les peuples marrons établis en Guyane française ont été constitués par des esclaves évadés des plantations du Surinam, puis réfugiés dans la forêt, aux abords des fleuves ou des cours d'eau ${ }^{3}$.

1 Cet article, rédigé en 2014, est une version largement remaniée et enrichie de « Marronnage et nationalité: le destin singulier des Boni (1836-1892) », Maude ELFORT, Vincent ROUX (dir.), La question autochtone sur le plateau des Guyanes, Aix-en-Provence, PUAM, 2013, pp. 89-116.

Cette recherche a été possible grâce au soutien financier apporté par le LABEX CEBA (projet ABIOS).

« This work has benefited from an « Investissements d'Avenir » grant managed by Agence Nationale de la Recherche (CEBA, ref. ANR-10-LABX-25-01). »

2 maître de conférences en droit public à l'Université des Antilles, LC2S. E-mail: yerri.urban@gmail.com 3 Pour une présentation synthétique des Marrons des Guyanes, cf. Richard PRICE, Sally PRICE, Les Marrons, 2ème éd., La Roque d'Anthéron, Vents d'Ailleurs, 2004 (1ère éd. 2003). Les Marrons de Guyane connaissent ou ont connu différentes appellations : Noirs Marrons, Bushinenge, Noirs Réfugiés. Le terme officiel privilégié est aujourd'hui Bushinenge, mais le terme «Marrons» présente l'avantage de désigner une 
Mais, tandis que les autres peuples restent liés au Surinam et sont couramment perçus comme en étant originaires, même si une partie de leurs membres a la nationalité française, les Boni (ou Aluku) $)^{4}$, quant à eux, sont couramment considérés comme Français, du fait d'un lien tissé avec la France au cours du XIXe siècle ${ }^{5}$. Ce lien ne peut être compris que dans le contexte très

catégorie de population reconnue juridiquement et présente dans plusieurs pays d'Amérique. Cf. également Marie-José JOLIVET, La question créole. Essai de sociologie sur la Guyane française, Paris, ORSTOM, 1982 ; M.-J. JOLIVET, « Modèle occidental et créolisation. L'exemple de la Guyane », L'homme, 2013/3, $\mathrm{n}^{\circ}$ 207-208, pp. 113-134.

S'agissant des Marrons des Amériques, cf. Richard PRICE (dir.), Maroon societies : rebel slave communities in the Americas, New York, Anchor Books, 1973 ; Jean MOOMOU (dir.), Actes du colloque " Marronnages ", Saint-Laurent-du-Maroni, novembre 2013, Matoury, Ibis Rouge, à paraître; Eric HOBSBAWM, « Postmodernism in the Forest » in E. HOBSBAWM, On History, New-York, New Press, 1997, pp. 192-200.

Sous un angle juridique et/ou administratif, cf. Maude ELFORT, «Pouvoirs publics, populations amérindiennes et bushinenge en Guyane française. Quelles relations depuis la décentralisation (1982-2008)?», Pouvoirs dans la Caraïbe, 16 (2010), pp. 67-90 ; Valérie DOUMENG, «L'état civil des populations marginales de la Guyane française» in Jean-François NIORT (dir.), Du Code noir au Code civil. Jalons pour l'histoire du droit en Guadeloupe. Perspectives comparées avec la Martinique, la Guyane et Haiti, Paris, L'Harmattan: 2007; p. 281-297; André NERON, « Rapport du conseil général de la Guyane avec les autorités coutumières amérindiennes et bushinengues », M. ELFORT, V. ROUX (dir.), La question autochtone sur le plateau des Guyanes: op. cit.; pp. 25-42.

Pour une approche juridique des Marrons des Guyanes au Surinam, cf. Ellen-Rose KAMBEL, Fergus MacKAY, The Rights of Indigenous Peoples and Maroons in Suriname, Copenhague/Moreton-in-Marsh, IWGIA/The Forest Peoples Program: 1999.

Pour une approche historique, administrative et très sensible aux questions juridiques d'un peuple marron au Surinam, cf. Silvia W. de GROOT, From isolation towards integration. The Surinam Maroons and their colonial rulers. Official documents relating to the Djukas (1845-1863), The Hague, Martinus Nijhoff: 1977. Pour une approche juridique et historique, cf. Yerri URBAN, « Les Marrons et le droit en Guyane française de 1836 à la « francisation » », J. MOOMOU (dir.), Actes du colloque « Marronnages », Saint-Laurent-duMaroni, op. cit.

4 Ce peuple fait l'objet d'une double désignation : le terme «Boni» est préféré par l'administration française et par les Amérindiens Wayana, le terme «Aluku» est préféré par les intéressés. Etant donné que cet article s'intéresse au lien avec la France, j'utiliserai le terme «Boni». Cf. Francis DUPUY, «Wayana et Aluku : les jeux de l'altérité dans le Haut-Maroni» in Gérard COLLOMB, Marie-José JOLIVET, Histoires, identités et logiques ethniques. Amérindiens, Créoles et Noirs Marrons en Guyane, Paris, CTHS, 2008, pp. 165-201, p. $170 \mathrm{n} .14$.

5 Il y a unanimité des anthropologues sur le fait que les Boni sont aujourd'hui considérés comme français, même si la situation peut être plus nuancée dans la pratique. Cf. par exemple, R. PRICE, S. PRICE: op. cit.; p. 93; M.-J. JOLIVET, «Histoires du marronnage ou le difficile renoncement des Ndjuka», in G. COLLOMB; M.-J. JOLIVET: op. cit.; pp. 77-105; p. 98.

Concernant la complexité de la situation pratique des Marrons en Guyane française en ce domaine, cf. M.-J. JOLIVET, Diane VERNON, « Droits, polygamie et rapports de genre en Guyane », Cahiers d'études africaines [En ligne], 187-188 | 2007, mis en ligne le 15 décembre 2010, consulté le 27 septembre 2012. URL : http://etudesafricaines.revues.org/8942. Les travaux en cours de l'anthropologue Catherine BENOIT de- 
Le rattachement d'un peuple marron a la france- les boni, de la guyane neerlandaise...

URBAN, Y.

particulier où il a pris forme.

On compte aujourd'hui six peuples marrons dans les Guyanes : trois d'entre eux sont traditinnellement établis sur ou vers la frontière entre le Surinam et la Guyane (Ndjuka, Paramaka $\mathrm{eBoni}^{7}$ ). Les trois autres sont traditionnellement établis au centre du Surinam

vraient enrichir les connaissances sur ce sujet. Cf. « Sans-Papiers amérindiens et noirs marrons en Guyane: la fabrique de l'étranger sur le fleuve Maroni », J. MOOMOU (dir.), Actes du colloque "Marronnages », op. cit.

La complexité de la situation actuelle des Marrons en Guyane est en grande partie liée à la guerre civile qui a eu lieu au Surinam de 1986 à 1992 et qui a notamment touché les Marrons. Cf. Clémence LEOBAL, «Bidonvilles et camps de réfugiés : le tournant des années 1980 pour la catégorisation des marrons à SaintLaurent-du-Maroni », ibid. et l'article précité de M.-J. JOLIVET.

6 Sur les Ndjuka, cf. S. de GROOT, From isolation towards integration, op. cit. ; Jean-Yves PARRIS, «Entre forêt et côte : l'inclusion négociée des Marrons ndjuka du Surinam», Autrepart (31): 2004; pp. 21-34. 7 Sur les Boni, cf. Tristan BELLARDIE, Les Relations entre Français et Bonis en Guyane française. Processus de colonisation et dépendance à travers le problème frontalier du Maroni (1836-1893), mémoire de maitrise d'histoire, Université de Toulouse-Le Mirail, 1994 ; Kenneth BILBY, The Remaking of the Aluku : Culture, Politics and Maroon Ethnicity in French South America, Ph. D. dissertation, Baltimore, John Hopkins University, 1990 ; K. BILBY, « Divided Loyalties: Local Politics and the Play of States among the Aluku », New West Indian Guide : 1989 : 63 (3/4) ; pp. 143-173 ; K. BILBY, « Swearing by the Past, Swearing to the Future : Sacred Oaths, Alliances and Treaties among the Guianese and Jamaican Maroons », Ethnohistory, 1997, 44 (4), pp. 655-689 ; S. de GROOT, « The Boni Maroon war 17651763, Surinam and French Guyana », Boletin de estudios latinoamericos y del caribe, 1975, n 18 , pp.3048; F. DUPUY, «Des esclaves marrons aux Bushinenge : le marronnage et ses suites dans la région des Guyanes», Cahiers d'histoire. Revue d'histoire critique, 89 (2002), pp. 29-39; F. DUPUY, «Wayana et Aluku», art. cité ; Wim HOOGBERGEN, The Boni Maroon wars in Suriname, Leiden, E. J. Brill, 1990; W. HOOGBERGEN, «Frères et ennemis. Aluku et Ndjuka de 1710 à 1860» in G. COLLOMB, M.-J. JOLIVET, op. cit., pp. 107-141; Jean HURAULT, Les Noirs Réfugiés Boni de la Guyane française, Dakar, IFAN, 1961 ; J. HURAULT, «Histoire des Noirs Réfugiés Boni de la Guyane française (d'après les documents de source française) », Revue française d'histoire d'outre-mer, 1960, XLVII, pp. 76-137; M.-J. JOLIVET, «Histoires du marronnage», art. cité ; Jean MOOMOU, Les marrons Boni de Guyane. Luttes et survie en logique coloniale (1712-1880), Matoury, Ibis Rouge, 2013 ; J. MOOMOU, Le Monde des Marrons du Maroni en Guyane (1772-1860). Naissance d'un peuple, les Boni, Matoury, Ibis Rouge, 2004; J. MOOMOU, Les Bonis au temps de l'âge de l'or et du grand «Takari » (1860 à 1869) : crises et espoirs. La question de l'évangélisation des Bonis dans les années 1880 : la mission du père Brunetti, mémoire de DEA d'histoire, Université des Antilles et de la Guyane (Schoelcher), 2003 ; J. MOOMOU, « Les Boni à l'âge de l'or et du grand takari (1860-1969) : « Temps de crises, temps d'espoir » ( (résumé de thèse), L'Atelier du Centre de recherches historiques [En ligne], 2009, mis en ligne le 07 mai 2010, consulté le 09 octobre 2012. URL : http://acrh.revues.org/2294 ; J. MOOMOU, «Les Bushinengue en Guyane : entre rejet et intégration de la fin du XVIIIe siècle aux dernières années du XXe siècles », in Serge Mam Lam Fouck, (dir.), Comprendre la Guyane d'aujourd'hui. Un département français dans la région des Guyanes, Matoury, Ibis Rouge, 2007, pp. 51-82 ; Miranda Frances SPIELER, Empire and Underworld. Captivity in French Guiana, Cambridge (Massachusetts)/London (England), Harvard University Press, 2012.

Enfin, en 1954, le géographe Jean HURAULT et la conservatrice Monique POULIQUEN ont retranscrit l'essentiel des documents d'archives relatifs aux Boni des XVIIIe et XIXe siècles conservés aux archives 
(Saramaka ${ }^{8}$, Matawai, Kwinti). Quatre d'entre eux sont présents en Guyane : ceux établis autour de la frontière surinamo-française, ainsi que les Saramaka, du fait d'une politique migratoire très incitative menée par les autorités coloniales françaises à leur égard. Si tous ces peuples sont aujourd'hui présents dans la zone côtière et dans les centres urbains, il faut insister sur le fait que Ndjuka, Paramaka et Boni sont présents tout le long du Maroni, les villages d'un même peuple étant situés sur la rive française et sur la rive surinamaise. Le «pays boni» est situé sur le Lawa, cours supérieur du Maroni. Si la grande majorité des villages est située sur la rive française, quelques uns se trouvent sur la rive surinamaise. D'après les tentatives d'estimation les plus récentes, les Boni comptent 11000 personnes. Les Ndjuka et les Saramaka sont de loin les plus nombreux, et l'étaient déjà au XVIIIe siècle. ${ }^{9}$

d'outre-mer et aux archives du ministère des affaires étrangères dans un ouvrage dactylographié : Documents pour servir à l'histoire des Noirs réfugiés Bonis de la Guyane française, Paris, 1954.

L'anthropologue Francis DUPUY a par ailleurs édité et richement annoté quelques récits de voyages fondamentaux quant à la connaissance de l'histoire des Boni : Les Arpenteurs des confins. Explorateurs de l'intérieur de la Guyane (1720-1860), textes réunis et présentés par F. DUPUY, Paris, CTHS, 2012.

Le texte le plus célèbre relatif aux Boni concerne leur lutte contre les autorités coloniales néerlandaises : Capitaine Jean-Gabriel STEDMAN, Voyage à Surinam et dans l'intérieur de la Guyane (trad. P.-F. Henry), Paris, F. Buisson, an VII-1798 (John-Gabriel STEDMAN, Narrative of a Five-Years Expedition Against the Revolted Negroes of Surinam, in Guiana on the Wild Coast of South-America; From the Year 1772, to 1777, Londres, J. Johnson and J. Edwards, 1796).

8 Sur les Saramaka, cf. R. PRICE, Les Premiers Temps. La conception de l'histoire des Marrons saamaka, 2ème éd. fr., La Roque d'Anthéron, Vents d'Ailleurs, 2013, trad. Michèle Baj Strobel avec la collaboration de l'auteur (1ère éd. fr. Paris, Seuil, 1994 ; First-Time. The Historical Vision of an Afro-American people, John Hopkins University Press, 1983); R. PRICE, To Slay the Hydra. Dutch Colonial Perspectives on the Saramaka Wars, Ann Arbor, Karoma, 1983.

9 S'appuyant notamment sur les données de l'INSEE et du recensement au Surinam de 2012, en intégrant le taux d'accroissement naturel élevé chez les Marrons (de 4,2 à 4,5\% en Guyane, probablement $5 \%$ au Surinam) et, en Guyane, le fait que de nombreux Marrons sont des étrangers en situation irrégulière, R. PRICE («The Maroon Population Explosion : Suriname and Guyane », New West Indian Guide, 87 (2013), pp. 323-327) estime qu'en 2014 la Guyane française compte 67000 Marrons, dont 27000 Ndjuka (sur un total de 90000 membres), 25000 Saramaka (sur 90000 membres), 10800 Boni (nombre que l'auteur pense avoir peut-être nettement sous-estimé- ibid., p. 326, note 5- et ce, sur un total de 11000 , les 200 restant étant établis aux Pays-Bas ) et 4900 Paramaka (sur un total de 11 000). Par ailleurs, absents de Guyane, les Matawai sont 7000 et les Kwinti sont 1 000. Le Surinam compte quant à lui 127000 Marrons et les Pays Bas 16 150. La population totale des Marrons des Guyanes serait donc aujourd'hui de 210000 individus, contre 100000 environ en 2000 et 40000 environ dans la seconde moitié des années 1960. En 2002, R. PRICE, en s'appuyant sur le recensement de 1999, («Maroons in Suriname an Guyane : how many and where?», New West Indian Guide, 2002, 76(1/2), pp. 81-88, p. 82) estimait que la Guyane française comptait 37200 Marrons, dont 14500 Saramaka, 14000 Ndjuka, 5900 Boni (sur un total de 6 000) et 2 800 Paramaka. Pour F. DUPUY («Wayana et Aluku», p. 170), qui écrivait en 2008, les Boni sont environ 4500 au total. 
C'est pour cette raison que les autorités néerlandaises conclurent avec eux, en 1760 et en 1762, ainsi qu'avec les Matawai en 1762 et en 1769, des traités de paix ${ }^{10}$, renouvelés dans les années 1830, par lesquels ils étaient désormais considérés non plus comme des esclaves fugitifs, mais comme des peuples libres et autonomes. Des tributs substantiels leur furent versés à l'occasion de la conclusion de ces traités ${ }^{11}$. Le versement plus ou moins régulier de tributs ( « cadeaux ») se poursuivit par la suite ${ }^{12}$. En contrepartie, ils cessaient leurs attaques et s'engageaient notamment à arrêter les esclaves en fuite et à les restituer aux planteurs moyennant une prime. Pour les autorités coloniales, ces Marrons devenaient ainsi leurs alliés, des «Marrons pacifiés».

Il en alla tout autrement des «proto-Boni» qui n'avaient reçu aucune proposition de paix : il s'agissait de petits groupes établis près des plantations, ce qui laissait penser qu'une autre solution pouvait être trouvée. Ils entrèrent en guerre contre les Néerlandais en $1768^{13}$. Au début des années 1770, divers groupes se rassemblèrent sous l'autorité d'un chef de guerre, Boni, et formèrent ainsi un nouveau peuple marron. En 1776-1777, les Boni traversèrent le Maroni et s'établirent sur la rive française. Ils entretinrent des relations pacifiques avec les Français, qui délaissaient alors cette partie de la Guyane. En 1789, les Boni attaquèrent à nouveau les plantations surinamaises et la guerre reprit. Elle s'acheva d'une manière dramatique : les Ndjuka finirent par y participer et en 1793, suite à une provocation due au fils de Boni, Agosu, massacrèrent les Boni réfugiés sur le Marouini ${ }^{14}$ et tuèrent notamment Boni lui-même. Mais il y eut des survivants. Après avoir tenu tête aux armées coloniales pendant plus de 20 ans, vaincus, mais par d'autres Marrons, les Boni continuèrent alors d'entretenir des liens complexes avec les $\operatorname{Ndjukas}^{15} \ldots$

10 Des traités avec les Marrons furent aussi conclus dans d'autres territoires américains, notamment en Jamaïque, dans les parties alors françaises et espagnoles de Saint Domingue, au Brésil, à Cuba, au Mexique, en Colombie. Cf. R. PRICE (dir.), Maroon societies, op. cit.; J. MOOMOU (dir.), Actes du colloque "Marronnages », Saint-Laurent-du-Maroni, op. cit.; E.-R. KAMBEL, F. MacKAY, op. cit., pp. 50-81, notamment pp. 55-60.

C'est d'ailleurs le traité conclu par la couronne britannique avec les Marrons de la Jamaïque en 1739 qui servit de modèle aux autorités néerlandaises. Cf. S. de GROOT: op. cit.; p. 11.

Sur la conclusion du traité avec les Ndjuka, ibid., pp. 8-15. Sur la conclusion du traité avec les Saramaka au travers de la tradition orale de ces derniers, cf. R. PRICE, Les Premiers Temps, op. cit., pp.273-296, notamment pp. 283-296 et surtout, au travers de nombreux documents d'archives néerlandais traduit en anglais, du même auteur, To Slay the Hydra, op. cit.

11 Cf. S. de GROOT, op. cit., pp. 10-11; R. PRICE (Les Premiers Temps, pp. 284-285) insiste sur l'énorme quantité de marchandises venues des Pays-Bas constituant le tribut des Saramaka; cf. plus largement du même auteur, To Slay the Hydra: pp.48-49; pp. 196-217.

12 Cf. par exemple S. de GROOT, op. cit., p. 14 ; K. BILBY, « Swearing by the Past, Swearing to the Future », art. cité, pp. 668-669; W. HOOGBERGEN, The Boni Maroon Wars in Suriname, op. cit., p. 185. 13 Pour les lignes qui suivent, cf. S. de GROOT, art. cité et op. cit., pp. 68-69; W. HOOGBERGEN, op. cit. et art. cité ; F. DUPUY, «Des esclaves marrons aux Bushinenge», «Wayana et Aluku», art. cités.

14 Affluent du Lawa, au sud de la Guyane française.

15 On peut notamment souligner que, nonobstant une «hostilité officielle», les échanges matrimoniaux sont fréquents entre les deux peuples. Cf. F. DUPUY, «Wayana et Aluku», p. 201; W. HOOGBERGEN, art. cité. 
Cette période fondatrice, toujours vivace dans la mémoire boni, et une présence constante, mais partielle parfois, du côté français, vont ouvrir la voie à une évolution originale par rapport aux autres peuples marrons.

Les Boni n'en appartiennent pas moins pleinement au monde marron des Guyanes.

En effet, comme toutes les sociétés marronnes, la société boni est strictement matrilinéaire ${ }^{16}$, ce qui signifie que tout individu appartient au clan de la mère et qu'il est placé sous l'autorité des oncles maternels, que les héritages s'opèrent d'oncle maternel à neveu utérin. Elle est aussi matrilocale : après mariage, chacun des époux continue de résider auprès de son clan, les hommes ayant la possibilité de multiplier les unions. L'unité sociale de base est le lo, le clan matrilinéaire. Schématiquement, il y a un village par lo. La société boni se répartit en plusieurs lo, hiérarchisés de manière rigide et compétitive pour des raisons historiques (l'épopée guerrière) et liées à la possession de forces magiques. L'ensemble est coiffé par le Gran Man ${ }^{17}$, autorité suprême, détenteur du pouvoir civil et spirituel, garant de l'unité du groupe et gardien des connaissances les plus sacrées. Sa fonction, à vie, se transmet essentiellement par héritage en ligne maternelle, ou de frère ainé à frère cadet, et une large part d'élection intervient entre plusieurs prétendants possibles. Il est secondé par un fiscali qui le représente ou le remplace quand c'est nécessaire. Chaque clan et/ou village est ensuite dirigé par un ou deux kapiten, eux aussi nommés à vie, lesquels sont assistés de basia. Les kapiten entourent le Gran Man dans toutes les décisions importantes. Ensemble, ils composent le noyau principal du kuutu (conseil), auquel participent tous les hommes d'un certain âge, les «grandes personnes» que l'on respecte. Ce conseil est un lieu de gestion des affaires publiques mais il est surtout chargé de rendre la justice : on y juge les vivants, mais aussi les morts.

Aujourd'hui, sur la base de délibérations du Conseil général de la Guyane, le Gran Man, les capitaines (kapiten) et les lieutenants (basia) sont, après leur désignation, agréés par le département qui leur verse une allocation mensuelle proportionnelle à leur rang (laquelle n'est pas une rémunération), leur attribue une tenue officielle (de conception militaire) et deux tenues de travail. ${ }^{18}$ Il en va de même pour les autres peuples marrons, n'étaient leurs Gran Man, établis au Surinam, et, avec une organisation différente, des Amérindiens ${ }^{19}$.

Considérés comme Français ${ }^{20}$, les Boni bénéficient toujours d'une reconnaissance de facto en tant que peuple doté d'une organisation politique et sociale qui lui est propre. Cohabitent ainsi,

16 Je suis ici, en la schématisant, la description de F. DUPUY (ibid., pp. 171-173), en laissant notamment de côté la dimension religieuse et l'importance du culte des ancêtres, sans lien direct avec les faits analysés dans cet article.

17 Le terme signifie à l'origine gouverneur.

18 Cf. M. ELFORT, art. cité, pp. 73-76; A. NERON, « Rapport du conseil général de la Guyane avec les autorités coutumières amérindiennes et bushinengues »,art. cité, pp. 33-41.

19 Cf. Irma ARNOUX, «Les Amérindiens dans la Guyane française : problèmes juridiques et politiques », RDP 1996-6, pp. 1615-1651, notamment pp. 1626-1627; dans une perspective politiste, Nicolas BONFAIT, La question amérindienne en Guyane française. Aspects administratifs, juridiques et politiques. Mémoire de DEA, Université des Antilles et de la Guyane, 1991.

20 C'est à partir de 1964, dans la perspective de la suppression de l'arrondissement de l'Inini (qui aura lieu en 1969), que les Amérindiens et les Marrons établis en Guyane, qui n’ont jusqu'alors pas d'état-civil, accèdent dans les faits à la nationalité française par le biais de jugements déclaratifs de naissances et se 
d'une part, une situation quasi-informelle ${ }^{21}$, dont la reconnaissance des autorités boni par le département est le symptôme, une zone grise, en dehors du droit ${ }^{22}$, où existe un peuple boni, et d'autre part, un droit où les Français n'existent qu'en tant qu'individus. Cette situation n'est pas différente de celle des autres peuples marrons et amérindiens établis aujourd'hui en Guyane. Elle est même dans l'ensemble plus juridique qu'auparavant, ce dont témoigne l'apparition récente d'études juridiques les concernant : la doctrine préférait naguère éviter le sujet. ${ }^{23}$

voient dotés de cartes d'identités. Cf. Stéphanie GUYON, « Des « primitifs » aux « autochtones ». Savoirs ethnologiques et politiques publiques en Guyane de 1946 à nos jours », Genèses 2013/2 n91, pp. 49-70, pp. 60-62; K. BILBY, «Divided Loyalties», art. cité, pp. 153-155 ; J. HURAULT, «La «Francisation» des Indiens de Guyane», Le fait public $n^{\circ}$ 16, mars 1970.

Sous un angle juridique, I. ARNOUX, « Les Amérindiens dans la Guyane française : problèmes juridiques et politiques », art. cité, p. 1625-1626 ; N. BONFAIT, La question amérindienne en Guyane française, op. cit., p. 35 ; Valérie DOUMENG, «L'état civil des populations marginales de la Guyane française»,art. cité, pp. 283-284, not. p. 284 : «Ainsi, des jugements déclaratifs d'état-civil étaient fondés non sur des preuves classiques relatives au lieu de naissance ou à la filiation, mais, notamment, sur le simple fait que la personne appartenait à la catégorie des primitifs».

21 Je me place ici d'un point de vue juridique, c'est à dire du point de vue d'une discipline qui ne serait plus rien sans le formalisme qui lui est propre. L'anthropologie, qui a pourtant en commun avec le droit «une érudition vagabonde et un air d'invraisemblance» (Clifford C. GEERTZ, «Civilisations et savoir : fait et droit en perspective comparée» in Savoir local, savoir global. Les lieux du savoir, Paris, PUF, 2012, trad. Denise Paulme, pp. 243-345, p. 243), aura bien sûr un autre point de vue. "De même que tout autre métier, science, culte ou art, le droit, qui est un peu de tout cela, propose le monde où ses descriptions ont un sens» (ibid., p. 252).

22 I. ARNOUX (art. cité, p. 1626) classe l'allocation versée aux « chefs coutumiers » dans « les aménagements de pur fait, sans base légale ».

23 Sous la IIIème République, les Marrons sont très généralement absents des ouvrages de droit colonial, et notamment d'ouvrages de référence, comme le Traité de droit colonial dirigé par Pierre DARESTE (Paris, 1931 pour le T.1 et 1932 pour le T.2) ou le Traité de la condition des indigènes en droit privé d'Henry SOLUS (Paris, Sirey, 1927). Et lorsque les Marrons sont exceptionnellement mentionnés, on se contente d'évoquer leur existence, sans se préoccuper de leur statut juridique. Il en va ainsi des Principes de colonisation et de législation coloniale d'Arthur GIRAULT : décrivant la population de la Guyane, il mentionne les « nègres des bois (Boschs, Bonis, Youcas)» qui « descendent d'anciens esclaves fugitifs retournés à la vie sauvage » (Paris, Sirey, 1921-23, 4 t., T.2, p. 128). Mais il n'en est nulle part question dans les parties proprement juridiques de son ouvrage.

On ne trouve pas plus de trace des Marrons sous la IVème République, alors que les dimensions de l'Outre-Mer français se réduisent.

Il en va autrement aujourd'hui, où la situation des Marrons est par exemple abordée dans le manuel de Droit des collectivités d'outre mer des Professeurs Jean-Yves FABERON et Jacques ZILLER (Paris, LGDJ, 2007, p. 173-178). Mais elle est abordée avant tout comme une question connexe à celle des Amérindiens, dans une section d'ailleurs intitulée "Les spécificités propres au statut des populations autochtones ». De fait, la situation des Marrons n'est très généralement traitée que conjointement à celle des Amérindiens, alors que les Amérindiens ont quant à eux fait spécifiquement l'objet d'articles de fond. A cela on peut trouver plusieurs explications : d'une part, une revendication plus importante de reconnaissance du droit coutumier de la part des Amérindiens, d'autre part et surtout, le fait que les Amérindiens soient considérés comme des autochtones, ce qui n'est généralement pas le cas des Marrons. 
C'est le rattachement à la France, notamment par le biais de l'investiture du Gran Man et du versement d'une allocation à ce dernier, qui fait aujourd'hui la singularité des Boni par rapport aux autres peuples marrons établis en Guyane, dont les Gran Man, quant à eux, demeurent rattachés au Surinam.

Comment un tel lien avec la France a t'il pu se construire?

Il peut paraître pour le moins paradoxal qu'un juriste se préoccupe d'une situation qui paraît échapper totalement à sa discipline. Pourtant, la dimension informelle de la situation des Boni n'est pas le produit d'une simple situation de fait, mais au contraire d'une évolution complexe où rapport formel et rapport informel vont s'entrecroiser, où les autorités coloniales vont bien souvent jouer du droit, de l'espace entre le droit et le fait, de la différence entre droit et pratique administrative, mais qui sera également, pour partie, construite par les Boni eux-mêmes.

Qu'ils soient liés indirectement avec les Pays-Bas (I) ou, nonobstant quelques hésitations, liés directement avec la France (II), les Boni verront ainsi leur histoire modelée par le droit.

\section{DU LIEN INDIRECT AVEC LES PAYS-BAS...}

La situation des peuples marrons, et notamment des Boni, ne peut être appréhendée qu'en regard de celle des peuples amérindiens, avec lesquels ils ont par ailleurs des rapports complexes ${ }^{24}$.

Le sort réservé aux Amérindiens en Guyane néerlandaise ${ }^{25}$ et en Guyane française ${ }^{26}$ présente des similitudes : on ne dispose pas de traités écrits ${ }^{27}$, les peuples amérindiens constituent des

24 Cf. par exemple F. DUPUY, « Wayana et Aluku », art. cité.

25 Cf. E.-R. KAMBEL, F. MacKAY, op. cit.; Simone DREYFUS, « Les réseaux politiques indigènes en Guyane occidentale et leurs transformations aux XVIIe et XVIIIe siècle ", L'Homme, 1992, tome 32, $n^{\circ}$ 122-124, pp. 175-198.

26 Les six peuples amérindiens établis aujourd'hui en Guyane proviennent de trois grandes familles linguistiques : Karib (Caraïbe) pour les Kalina (Galibi) et les Wayana; Tupi pour les Wayapi (Oyampi) et les Emerillons (Teko); Arawak pour les Arawak proprement dit et les Palikur. Trois peuples sont établis sur la côte : Kalina (qui dominent), Arawak et Palikur; trois sont établis à l'intérieur : Wayana, Wayapi et Emerillons. Cf. pour une première approche, Pierre GRENAND \& Françoise GRENAND, Les populations amérindiennes de Guyane française, Cayenne, ORSTOM, 1978. Plus largement, cf. Jean-Marcel HURAULT, Français et Indiens en Guyane, Paris, UGE, coll. « 10/18 », 1972, not. pp. 215-226 ; P. GRENAND, Ainsi parlaient nos ancêtres. Essai d'ethno-histoire "Wayapi », Paris, ORSTOM, 1982 ; P. GRENAND, «Que sont devenus les Amérindiens de l'Approuague? Réflexions autour d'une histoire peu documentée » in Serge MAM LAM FOUCK \& Jacqueline ZONZON, L'histoire de la Guyane depuis les civilisations amérindiennes, Matoury, Ibis Rouge, 2006, pp. 105-123; P. GRENAND, F. GRENAND, « L'occupation amérindienne : ethnoarchéologie, ethnohistoire » in L'archéologie en Guyane, Cayenne, APPAAG éditions, 1997, pp. 57-71; G. COLLOMB \& Félix TIOUKA, Na'na Kali'na. Une histoire des Kali'na en Guyane, Matoury, Ibis Rouge, 2000 ; G. COLLOMB, « Du “capitaine” au “chef coutumier” chez les Kali'na », Ethnologie française, 1999, $\mathrm{n}^{\circ}$ XXIX/4, pp.549-557.

27 S'agissant du Surinam, des traités écrits ont notamment été conclus par les Néerlandais avec les principales « nations indiennes » en 1684-1685 mais ont été égarés depuis (E.-R. KAMBEL, F. MacKAY, op. cit., pp. 51-55, not. pp. 51-52); par contre, il ne paraît pas y avoir eu de traités écrits en Guyane. Sur la conclusion d' " alliances » en Guyane et les pratiques les formalisant (notamment le don de « cadeaux »), cf. P. GRENAND, Ainsi parlaient nos ancêtres, op. cit., pp. 137-144 et, concernant la conclusion de l'alliance 
" nations indiennes », des "nations libres $~^{28}$, ce qui n'empêche pas la mise d'Amérindiens en esclavage $^{29}$. Français et Néerlandais reconnaissent parmi eux des intermédiaires dénommés « capitaines » et les dotent d'attributs, d'insignes démontrant leur reconnaissance ${ }^{30}:$ la canne à pommeau d'argent, notamment ${ }^{31}$, " marquée du nom du Capitaine représente une marque de reconnaissance donnée par la France ou par la Hollande, parfois par les deux, aux Capitaines amérindiens ».32 La liberté d'émigration et d'installation des Amérindiens, qui peuvent facilement changer de lieu d'établissement, est reconnue par les deux colonies, surtout dans la zone côtière, la plus contrôlée. Il en va notamment ainsi des Kali'na, alliés aussi bien des Français que des Néerlandais ${ }^{33}$.

Du côté français, la situation des Amérindiens au XIXè siècle était résumée ainsi par Bagot, un commerçant itinérant, dans les années 1840 : "Les Indiens sauvages et même les civilisés ne sont soumis à aucun règlement; ils n'ont même pas qualité de citoyens, ne figurent pas sur les états-civils, ne paient aucune contribution et tout cela, dit-on, parce qu'ils ne sont pas assez civilisés. Ils n'ont donc pas de chef, n'étant soumis à nos lois. ${ }^{34}$ Dans cette période qui est pour eux particulièrement dramatique d'un point de vue démographique, les Amérindiens continuent, plus encore qu'au siècle précédent (qui connut des tentatives d'intégration plus poussées), de se voir reconnaître une totale autonomie pour régler leurs propres affaires internes, un droit à la migration, et une liberté de principe. Les autorités françaises (comme les néerlandaises) continuent de reconnaître des capitaines. ${ }^{35}$

Cette situation, en dehors du droit, des Amérindiens, surtout du côté français, contraste avec celle des peuples marrons constitués au Surinam qui, ne peuvent, quant à eux, être appréhendés si

entre la France et les Wayapi, auparavant alliés des Portugais (voire des Brésiliens), au début du XIXe siècle, selon la tradition orale wayapi, Ibid., p. 299-303.

28 E.-R. KAMBEL, F. MacKAY, op. cit., pp. 52-53; J. HURAULT, Français et Indiens en Guyane, op. cit., not. pp. 215-216.

29 S'agissant des Néerlandais, avec lesquels le phénomène prend une ampleur certaine, cf. S. DREYFUS, art. cité, pp. 83-90; G. COLLOMB, F. TIOUKA, Na'na Kali'na, op. cit., pp. 41-42; s'agissant des Français, avec lesquels, le phénomène a eu une portée très limitée, notamment du fait du principe de la liberté des Indiens (qui constituaient $6 \%$ des esclaves en 1685 et 1\% en 1739), cf. Frédéric REGENT, La France et ses esclaves. De la colonisation aux abolitions (1620-1848), Paris, Hachette, coll. « Pluriel », 2009 (Paris, Grasset, 2007), pp. 38-40; Frédéric CHARLIN, Homo servilis. Contribution à l'étude de la condition juridique de l'esclave dans les colonies françaises (1635-1848), Thèse pour le doctorat en droit, Université Pierre Mendès-France de Grenoble, 2009, pp. 32-33; Mme MARCHAND-THEBAULT, « L'esclavage en Guyane française sous l'ancien régime », Revue française d'histoire d'outre-mer, t. 47, n 166, 1960, pp. 5-75, pp. 10-11.

30 J. HURAULT, Français et Indiens en Guyane, op. cit., not. pp. 216-217 ; Gérard COLLOMB, « Du "capitaine" au "chef coutumier" chez les Kali'na », art. cité.

31 Il peut également s'agir de médailles, d'uniformes, de sabres etc...

32 G. COLLOMB, F. TIOUKA, op. cit., note 80, p. 95.

33 Ibid., pp. 46-47, pp. 59-85; J. HURAULT, Français et Indiens en Guyane, op. cit., pp. 215-216.

Les Kalina effectuèrent des razzias pour pourvoir aux besoins en esclaves du Surinam et participèrent à la répression des Marrons, notamment des Boni.

34 Rapport de M. Bagot sur les Indiens de l'Oyapock, 1849 in F. DUPUY, op. cit., p. 160.

35 Cf. notamment G. COLLOMB, F. TIOUKA, pp. 77-85. 
l'on ignore l'existence des traités de paix conclus par la plupart d'entre eux avec les Pays-Bas. Il en va ainsi des Boni dont la condition jusqu'en 1860 revêt deux dimensions, l'une qui relève de la seule Guyane néerlandaise, l'autre des Guyanes française et néerlandaise : d'un point de vue strictement néerlandais, ils n'ont pas conclu de traité de paix et par là même ne se voient pas reconnaître leur liberté ; d'un point de vue franco-néerlandais, ils sont placés sous la domination d'un peuple marron «pacifié», les Ndjuka - et donc sous la domination indirecte des Néerlandais.

\section{A. L'ABSENCE DE TRAITÉ DE PAIX AVEC LES PAYS-BAS}

Libres de facto, les Boni n'ont pas de véritable statut juridique, avec les avantages mais aussi les contraintes y afférent.

Pourtant, l'évolution de leur situation ne peut être comprise sans connaître ce statut des «Marrons pacifiés», qui est toujours présent en arrière plan.

Les traités de paix conclus par les Pays-Bas avec les Ndjuka, les Saramaka et les Matawai se limitent (en partie) à sanctionner une situation de fait, et ne sont que partiellement respectés des deux côtés. Evènements particulièrement marquants dans la mémoire des peuples marrons qui les ont conclus ${ }^{36}$, véritablement négociés ${ }^{37}$, ils n'en ont pas moins impulsé leur propre dynamique.

Le traité de paix conclu par les Ndjuka en 1760 est fondamental ici, non seulement parce qu'il est le premier, mais à cause du lien des Ndjuka avec les Boni. ${ }^{38}$ Ce traité avait été solennellement conclu à Steenkreek près d'un affluent du Maroni, la rivière Djuka (d'où le nom du peuple marron) le 10 octobre $1760 .{ }^{39}$ Les « Indiens libres » alliés aux Néerlandais bénéficient aussi du traité. ${ }^{40}$

Motivé par la volonté de « diviser pour mieux régner » en concluant des paix séparées avec certains groupes marrons, mais aussi par le coût économique excessif des combats, inspiré des traités passés par la Grande-Bretagne avec les Marrons de la Jamaïque en 173941, il revêt une double dimension, de droit privé et de droit public. La dimension de droit privé, c'est l'affranchissement

36 Pour les Saramaka, cf. R. PRICE, Les Premiers Temps, op. cit., pp. 273-296.

37 Le contenu du tribut versé à l'occasion du traité donne lieu à des réclamations des chefs marrons (cf. S. de GROOT, op. cit., pp. 10-11; R. PRICE, Les Premiers Temps, pp. 283-285 et To Slay the Hydra, not. pp. 12-36), mais elles peuvent aussi porter sur le contenu des clauses du traité (E.-R. KAMBEL, F. MacKAY, op. cit., p. 58 ; W. HOOGBERGEN, op. cit., pp. 27-28).

38 De longs extraits du texte de 1760 sont traduits en anglais par S. de GROOT (op. cit., pp. 11-12).

Plus largement, cf. Ibid., pp. 8-13 ; E.-R. KAMBEL, F. MacKAY, op. cit., pp. 58-59; W. HOOGBERGEN, op. cit. , pp. 26-29.

Le traité avec les Saramakas de 1762 est quant à lui intégralement traduit en anglais dans R. PRICE, To Slay the Hydra, op. cit., pp. 159-165.

39 S. de GROOT, op. cit., p. 11, p. 13; R. PRICE, To Slay the Hydra, op. cit., not. pp. 43-47. Plus largement, sur la conclusion des traités de paix avec les Marrons du Surinam au XVIIIe sièce, cf. E.-R. KAMBEL, F. MacKAY, op. cit., pp. 64-65.

$40 \mathrm{Cf}$. art. $5:$ «...; whereas the free Indians, who are on terms on friendship which us, are also included under the terms of this treaty, and must not be molested in any ways ». S. de GROOT, op. cit., p. 12.

41 Ibid., pp. 8-11. 
collectif : les Ndjuka cessent d'être des esclaves évadés et se voient reconnaître la liberté. La dimension de droit public, c'est la reconnaissance des Ndjuka en tant qu'entité politique ${ }^{42}$.

Les Ndjuka prennent soin d'assurer leur autonomie durant les négociations, faisant notamment en sorte d'échapper à la justice criminelle néerlandaise. Le traité n'aborde que les questions de compétence en matière criminelle, mais la totale autonomie des Ndjuka dans les autres domaines (c'est-à-dire, transposé en langage juridique, les autres affaires non-criminelles, les droits d'usage, le mariage, l'héritage et les autres aspects de la vie sociale) sera, de facto, reconnue. ${ }^{43}$

Ils s'engagent à informer les autorités coloniales de la mort de leurs chefs, et leurs successeurs doivent être approuvé par les Néerlandais, lesquels interviendront, à l'occasion ${ }^{44}$. Des otages sont échangés : pendant que des Ndjukas sont obligés de vivre à Paramaribo, un "posthouder» ${ }^{45}$, un militaire, est installé dans le village du Gran Man. Il est notamment chargé de s'assurer du respect du traité ${ }^{46}$.

Puisque les Ndjuka s'engagent à ne plus attaquer les plantations et à se tenir à distance d'elles (ils peuvent s'établir où ils le souhaitent, à condition que ce soit au minimum à une distance de

42 Cette situation est résumée par l'art. 1er du traité de 1762 avec les Saramaka : "The aforementioned Bush Negroes from Upper Saramacca and Suriname, with forgiveness for all that has passed, shall be recognized as free persons, provided that they never again commit hostilities against the whites, be they Christians or Jews, likewise including the free Indians ». R. PRICE, To Slay the Hydra, p. 159.

43 Cf. art. 13 : "They, the Maroons, shall in future no longer pass sentence of death upon anyone without the knowledge of the authorities of this colony, but shall hand over the offender if they consider him to deserve death penalty_together with the charges against him, to the Governement, which is the only competent court in matters of life and death; the punishment of all other offenses shall be left in their hands, however. » S. de GROOT: op. cit.; p. 12.

Cf. E.-R. KAMBEL, F. MacKAY: op. cit.; p. 58, pp. 66-67.

Dans une perspective plus large, cf. Natalie ZEMON DAVIS, «Judges, Masters, Diviners : Slaves' Experience of Criminal Justice in Coloniale Suriname », Law and History Review, November 2011, Vol. 29, $\mathrm{n}^{\circ} 4$, pp. 925-984, qui aborde notamment la justice criminelle chez les Saramaka, pp. 956-966.

44 Cf. Traité de 1762 avec les Saramaka, art. 4 : "They shall report wo their chiefs are, and the death or change of these, they shall first send news of who replace them, in order to receive approval and recognition from the Government ». R. PRICE, To Slay the Hydra, p. 160.

Le terme Gaanman (Gran Man) dans la version en saramaccan du traité ne désigne que le Gouverneur néerlandais. Entretien avec R. PRICE, novembre 2013.

Cf. E.-R. KAMBEL, F. MacKAY, op. cit., p. 66, note 80 p. 78; J.-Y. PARRIS, art. cité, pp. 29-32.

45 Titulaire du poste (postholder en anglais).

$46 \mathrm{Cf}$. art. $12:$ : A sufficient number of whites shall live among them to see to it that all these conditions are observed; and in return they shall allow twelve Creoles from their midst, all of them sons of Chiefs or the most prominent among them, to live among the whites in Paramaribo, though with permission to change the same every year ». En application de cette disposition, un sergent blanc fut affecté avec deux soldats dans le village du Gran Man. Cf. S. de GROOT, op. cit., p. 12, pp. 12-13; E.-R. KAMBEL, F. MacKAY, op. cit., pp. 58-59.

Les Néerlandais ont pu également placer des posthouder auprès d'Amérindiens, mais la fonction n'était pas identique. Ibid. 
10 heures de la zone des plantations, sur la côte $)^{47}$, les autorités coloniales leur versent en principe régulièrement un tribut ( « cadeaux ») composé de biens manufacturés, notamment des armes et des munitions, biens que les « Marrons pacifiés» se procuraient auparavant lors de raids dans lesdites plantations ${ }^{48}$. Dans la pratique, le versement du tribut n'est pas toujours régulier et donne lieu à de multiples difficultés, fruit du mécontentement des autorités coloniales ou du mécontentement des Marrons $^{49}$. Ce tribut complète les échanges commerciaux très encadrés que les Ndjuka peuvent avoir avec la côte (seulement en groupes de 10 ou 12 hommes et en informant préalablement le gouverneur)..$^{50}$

Les Ndjuka s'engagent également à restituer aux Blancs les esclaves en fuite qui se réfugient chez eux moyennant une prime ${ }^{51}$. Ils continueront d'en accueillir. ${ }^{52}$

Devenus les alliés des Néerlandais, les Ndjuka s'engagent enfin à participer à leurs luttes contre les esclaves en fuite et contre les Indiens ennemis ${ }^{53}$, clause qu'ils n'appliqueront pas toujours.

$47 \mathrm{Cf}$. art. $3:$ "They shall remain without restriction in the places at present inhabited by them, and all the necessary adjoining land, provided this is no closer than at least two days'or ten hours 'travelling from any plantation; if, however, they wish to settle anywhere else, whether this be further upstream or elsewhere, they shall be bound to obtain prior permission from the Government of these territories, the same applying if they wish to prepare building-timber for purposes of sale upstream in accordance with the local custom ». S. de GROOT, op. cit., p. 11.

Cf. E.-R. KAMBEL, F. MacKAY, op. cit., p. 58.

48 Cf. Traité de 1762 avec les Saramaka, art. 13 : «Toward the conclusion of this peace, they are to be allowed tools, etc. which they requested and were granted according to the list appended here.(...) » et art. 14. R. PRICE, To Slay the Hydra, pp. 162-163, p. 217 pour la liste des biens figurant dans le tribut.

49 S. de GROOT, op. cit., p. 14; Jean-Yves PARRIS, «Entre forêt et côte : l'inclusion négociée des Marrons ndjuka du Surinam», art. cité, p. 25.

$50 \mathrm{Cf}$. art. 10 : "They shall be free to convey any of their produce, cattle, goods, timber, etc., _though never in groups larger than ten or twelve persons at a time_for the purpose of selling the same in Paramaribo or any other place stipulated, on condition that they report to the Governor immediately upon arrival, in order to give notice of their presence and of the goods they intend to offer for sale. " S. de GROOT, op. cit., p. 12. E.-R. KAMBEL, F. MacKAY, op. cit., p. 58.

$51 \mathrm{Cf}$. art. $4:$ : If any slaves should defect to them after the Amnesty and the Treaty and the signing thereof, they, the Maroons, shall be bound to return the same and surrender them to whites without exception, for which they shall receive a due reward in money or kind, in accordance with an agreement to be made especially about this, namely ten to fifty Dutch guilders for every slave so returned. For convenience sake they shall be allowed to surrender the same to the nearest white for delivery to the nearest Council member or Citizen's Guard Officer whereupon the reward shall be paid out to them forthwith. " S. de GROOT, op. cit., p. 11.

E.-R. KAMBEL, F. MacKAY, op. cit., p. 58.

52 Sur l'attitude des Ndjuka à l'égard de ces esclaves en fuite, cf. S. de GROOT, op. cit., pp.14-16, pp. 98105; sur l'attitude des Saramaka, cf. R. PRICE, To Slay the Hydra, pp. 39-40.

53 Cf. art. $5:$ : They, the pacified Negroes and their successors, shall do everything in their power to capture any slaves running away after te conclusion of this treaty, as well as any hostile Indians, and shall surrender the same, or, if necessary, kill them. Furthermore, they shall be bound to try and track down and capture any runaway slaves immediately upon being notified of the latter's escape by the Governor; and in the event of a rebellion or trouble on any plantation or in any part of the colony, their Chiefs shall see to it that, at 
Le rattachement d'un peuple marron a la france- les boni, de la guyane neerlandaise...

URBAN, Y.

Les traités avec les Saramaka (1762) et les Matawai (1762 et 1769) reprennent dans l'ensemble les dispositions du traité de 1760. Il est notamment interdit aux Saramaka de conclure des traités avec les Ndjuka. ${ }^{54}$ On a ici la première manifestation d'une tendance du pouvoir colonial à limiter l'autonomie externe des peuples marrons, tendance qui ne fera que se renforcer par la suite.

Les renouvellements de traités de 1835,1837 et $1838^{55}$ (le traité avec les Ndjuka date de $1837^{56}$ ), tout en reprenant en partie les dispositions et parfois pratiques antérieures, sont plus contraignants, mais seront eux aussi partiellement appliqués : l'obligation pour les « Marrons pacifiés » de restituer les esclaves en fuite moyennant une prime ${ }^{57}$ et l'obligation pour les autorités coloniales d'offrir régulièrement des «cadeaux » (que les observateurs extérieurs préfèrent qualifier de tribut $)^{58}$ se voient ainsi nettement encadrées mais seront loin d'être scrupuleusement respectées ${ }^{59}$.

the first summons of the Governor or the Governor-in-Council, the required number of male members of the tribe shall be placed at his disposal. They shall undertake to be on the greatest service to the whites, also against others runaways_in the first place the runaways banded together between the Marowyne and Cottica Rivers_whom they shall help exterminate, especially if these attacks whites or commit hostile acts of any other kind; whereas the free Indians, who are on terms on friendship which us, are also included under the terms of this treaty, and must not be molested in any ways. . Ibid., p. 12.

54 Cf. Traité de 1762 avec les Saramaka, art. 12 in R. PRICE, To Slay the Hydra, p. 162.

E.-R. KAMBEL, F. MacKAY, op. cit., pp. 59-60.

55 Ibid., p. 60, p. 67; S. de GROOT, op. cit., p. 16. Le traité avec les Saramaka date de 1835 et celui avec les Matawai de 1838.

56 De longs extraits du texte de 1837 sont traduits en anglais par S. de GROOT (op. cit., pp. 16-17, pp. $53-$ 54, p. 69, pp. 88-89, pp. 98-99).

S'agissant du renouvellement du traité de 1760 avec les Ndjuka lors de l'occupation britannique, en 1809, qui concerne directement les Boni, cf. infra.

$57 \mathrm{Cf}$. art. $6:$ : They shall not allow any runaway slave, whether belonging to a plantation or to a private person, to live with them, much less fetch elsewhere, buy or hire any slaves, or take the same to their villages or places of work, but on the contrary, shall detain any escaped slaves, both male and female, who may still be living among them, as well as any who may come to them or whom they may find, wherever this may be, and surrender them to the nearest military post, there to receive a voucher accordingly, which they may take to Paramaribo in order to receive the reward of sixteen guilders for each them beyond the cordon, a reward of fifty guilders for each captured runaway will be paid them. The Postholder must be informed accordingly in advance and give permission for such an expedition to take place, however. »Ibid., pp. 98-99.

$58 \mathrm{Cf}$. art. $21:$ : The gifts which will be presented to them punctually and regularly every four years if they behave well and in such a way as to be worthy of the same, will be inspected and taken receipt of in Paramaribo by four chiefs of their choosing; two of these will remain in Paramaribo until such time as the gifts have been distributed, while two must escort the goods to Armina post, where each chief will come to fetch the goods that are rightfully his, to take these to his village and distribute them among his people at his own discretion, in such a way that there will be nothing for anyone to find fault with, much less for anyone to dispute. The Government will also see to it that the goods are sent to each chief separately, so that it will be impossible for any of them to be treated unfairly. They will be forbidden to trade, sell or give any of these presents to anyone who is not on peaceful terms with the Government, and no condition to slave. »Ibid., pp. 53-54.

59 Ibid., notamment p. 20; sur les multiples difficultés liées au versement du tribut, cf. pp. 53-61 et sur l'application de la clause sur les esclaves en fuite cf. pp. 98-105. 
Ils marquent la volonté du pouvoir colonial d'affirmer la subordination des autorités marrons : les Gran Man doivent faire allégeance à la couronne néerlandaise ${ }^{60}$, les peuples marrons n'ont pas le droit de conclure de traités entre eux ni d'entrer en relation avec un pouvoir étranger. Il ne s'agit donc plus ici de la reconnaissance d'une quasi-indépendance ou d'une indépendance tout à fait concevable pour ce type d'entités politiques dans le contexte du droit des gens du XVIIIe siècle, mais de la nette affirmation de l'absence de souveraineté externe des entités politiques marrons. On entre ici, au minimum, dans une logique de protectorat. Mais, comme on le verra, la pratique s'éloignera grandement de ces principes.

Quant à l'autonomie interne, elle se voit, dans une moindre mesure, atténuée : l'intervention des juridictions néerlandaises en matière criminelle est plus marquée.

L'heure est à la stabilisation et au cantonnement ${ }^{61}$ : les Marrons pacifiés doivent désormais demeurer sur leurs territoires qui seront délimités et doivent obtenir un passeport pour avoir le droit de voyager au dehors, en nombre limité et avec une quantité de marchandises limitée ${ }^{62}$. Ces dispositions n'empêcheront pas les Ndjuka de continuer leurs trafics avec les esclaves et, plus largement, entre la côte et le Maroni ${ }^{63}$.

Ces traités néerlandais du XIXe siècle sont expressément intégrés à la législation de la colonie $^{64}$ par le biais de «résolutions». Ces dernières sont ratifiées par le gouverneur du Surinam et par le ministre des colonies. Les traités font alors partie de la législation du Surinam.

Les mesures les plus restrictives quant à la circulation des « Marrons pacifiés » contenues dans les traités des années 1830 sont abandonnées en 1856 : la baisse du nombre d'évasions d'esclaves, la diminution de la peur d'une « menace marron », et les difficultés d'application des dispositions des traités entrainent notamment la suppression des plafonnements quant à la quantité de biens et quand au nombre de personnes. ${ }^{65}$

C'est dans la continuité de cette libéralisation qu'est décidée la suppression du tribut en $1857^{66}$ : pouvant circuler plus facilement et pouvant travailler plus facilement sur la côte, les « Marrons pacifiés » peuvent désormais acquérir plus aisément les biens qui composaient le tribut

60 Cf. art. $13:$ : In the event of the death of a Paramount Chief or lesser Chief they shall be free to choose his successor; however, they must be immediately inform the post holder accordingly, and hand over to him the Chief's staff, metal chain, etc. He shall then_after ascertaining that the newly chosen chiefs conduct has been such as to render him worthy of the Government's confidence_send a written report to the Government. After confirmation of the appointment by the Government, the chief must come to swear an oath of allegiance. » Ibid., p. 17. C'est moi qui souligne.

61 Il faut également avoir la permission du posthouder pour acheter des armes. Cf. art. 26, Ibid., p. 17.

62 Cf. art. 15 : « Passes for Paramaribo or any other place (....) shall never be issued to more than forty of them at a time; in order to obtain said passes they must apply to the post holder, if present, or to the assistant post holder, between 8 a.m. and 4 p.m., giving details of their own names and those of their chief and villages, of the number of guns both working and defective, of the contents of their cargo, of the articles they intend to buy, of any leopard heads they are carrying, and any other information he may require. " Ibid., et pour une présentation de l'ensemble de ces mesures, Ibid., pp. 88-89.

63 Ibid., pp. 89-98.

64 E.-R. KAMBEL, F. MacKAY,op. cit., p. 65, pp. 67-68.

65S. de GROOT, op. cit., pp. 61-66, not. pp. 61-62.

66 Ibid., pp. 66-68. 
(notamment des biens manufacturés). Or c'était la difficulté qu'avaient les « Marrons pacifiés » d'accéder à ces biens qui justifiait notamment la livraison de « cadeaux » du coté néerlandais. Les tributs n'étant plus utiles dans le système économique marron d'un point de vue néerlandais, il est décidé d'y mettre fin en y substituant le versement régulier d'une somme (qualifiée indifféremment d'allocation, de salaire ou de pension ${ }^{67}$ ) aux trois Gran Man. Pour que cette mesure soit perçue comme une faveur, on charge les posthouder d'inviter les Gran Man à solliciter la mesure auprès du Gouverneur. Les posthouder sauront se montrer convaincants : la mesure sera sollicitée et, avec l'accord du ministère des colonies, les sommes seront versées. Toutefois, on offrira des « cadeaux » aux Marrons de passage en ville.

Au delà de situations relativement courantes dans le contexte de l'époque, les traités de paix n'en auront pas moins créé un rapport difficile à appréhender pour le juriste : d'une part, l'approbation du nouveau Gran Man laisse penser que les Ndjuka sont subordonnés au pouvoir colonial, mais le versement d'un tribut peut paraître comme le signe d'une certaine soumission de la part du pouvoir colonial. Malgré les efforts des autorités coloniales néerlandaises pour qualifier ce phénomène de simple remise de présents, le caractère symbolique et humiliant propre à un tribut est perçu. Un planteur néerlandais évoque ainsi, en 1778, des " conditions humiliantes », "une sorte de tribut annuel sous le nom de présents qui, à l'origine, n'est rien de moins que la reconnaissance publique de leur supériorité $\gg .^{68}$ De plus, ils entremêlent en permanence la question de l'affranchissement et celle de l'indépendance politique. Mais l'esclavage finira par être aboli au Surinam en 1863.

Les Néerlandais n'en auront pas moins par la suite le plus grand mal à qualifier la situation des «Marrons pacifiés». ${ }^{69}$

67 Respectivement « allowance », « salary » et « pension » in Ibid., note 55, p. 110.

68 « (...) a kind of annual tribute under the name of presents which, at base, is nothing less than the public recognition of their superiority (...) ». Cité in R. PRICE, To Slay the Hydra, p. 38 et, plus largement, sur le caractère à la fois symbolique et économique du tribut, pp. 38-40.

Les Français pourront insister eux aussi sur l'humiliation du tribut. Voici un exemple : «Le tribut que les Hollandais payent aux Bosses Nègres, quelque honteux qu'il paraisse, est exactement le même que celui que les Anglais leur payaient (...).» Rapport de Vaillant (11 février 1821), J. HURAULT, M. POULIQUEN, Documents pour servir à l'histoire des Noirs réfugiés Bonis, op. cit., p. 125

Le terme «Boss » ou « Bosh » sert aux «Blancs » à désigner les Ndjuka, mais parfois aussi les Marrons en général. F. DUPUY, op. cit., note 14 p. 151.

69 Dans le premier quart du XXème siècle, alors qu'il est admis que les «peuples sauvages» n'ont pas d'existence internationale et ne peuvent conclure de traité, les « Marrons pacifiés » seront qualifiés d'«Etat dans l'Etat» (commission des rapporteurs, en 1918), de «nation amie» par un membre des états coloniaux, et, en 1924, un membre de la première chambre néerlandaise se demande s'ils doivent être perçus «comme des citoyens néerlandais ou comme des alliés». Pour le Gouverneur Van Heemstra, en 1923, la relation des Marrons avec le gouvernement n'est pas différente de celle avec les autres habitants de la colonie, «en théorie». Un professeur de droit néerlandais, Van Vollenhoven, perçoit une contradiction entre le «règlement de gouvernement», une sorte de constitution, qui est complètement silencieux sur l'existence des Marrons, et le fait que le gouvernement autorise un Gran Man marron à envoyer une lettre à la Société des Nations au nom de son peuple. Plus tardivement, un autre juriste néerlandais, Quintus Bosz, qualifie les traités conclus avec les Marrons de «contrats politiques internes», mais sans définir juridiquement l'expression. 
Dans ce contexte, les Boni, avec les Paramaka et les Kwinti, appartiennent à ces peuples marrons qui n'ont pas conclu de traité ; toutefois, à la différence de ces derniers, ils deviennent une affaire franco-néerlandaise, au moment où les traités des années 1830 sont conclus.

\section{B. L'ACCORD FRANCO-NÉERLANDAIS SUR LA DOMINATION NDJUKA}

Les autorités coloniales du Surinam décident de préciser la situation des Boni à l'occasion de renouvellements du traité de paix avec les Ndjuka ${ }^{70}$, d'abord en 1809, alors que la colonie est aux mains des Britanniques ${ }^{71}$, puis lors du renouvellement de $1837^{72}$ : les Ndjuka sont avant tout chargés d'empêcher les Boni d'accéder à la zone des plantations (et même à «tout district de la colonie » en 1837) et d'attaquer les blancs. ${ }^{73}$ Les Ndjuka sont ainsi dispensés de l'application des dispositions relatives aux esclaves révoltés et évadés aux Boni qui, du fait de ce régime dérogatoire, se voient interdire toute relation économique directe avec la côte : les Boni sont des esclaves rebelles traités de manière spécifique.

Dans les faits, les Ndjuka, présents sur le Tapanahoni, un des affluents du Maroni, et surtout à la confluence entre le Lawa et le Tapanahoni, font en sorte d'être les seuls intermédiaires com-

Ce discours contradictoire s'explique par le fait que les Néerlandais ont pu croire que les traités de paix des années 1830 contenaient la reconnaissance de leur autorité totale sur les Marrons. Toutefois les «Marrons pacifiés» ont toujours eu une opinion différente sur ce point, et continueront de baser leurs revendications sur les traités.

Je suis ici E.-R. KAMBEL, F. MacKAY, op. cit., pp. 61-75.

70 On sait très peu de choses sur les Boni entre 1793 et 1836. Cf. S. de GROOT, op. cit., p.69 et art. cité, p. 47; W. HOOGBERGEN, art. cité, pp. 137 ss. et op. cit., pp. 184 ss.; F. DUPUY, art. cité, p. 183.

71 S. de GROOT, op. cit., p.69 et art. cité, p. 47; E.-R. KAMBEL, F. MacKAY, op. cit., p. 59; W. HOOGBERGEN, art. cité, p. 135 et op. cit., p. 185.

72 S. de GROOT, op. cit., pp. 69-70.

73 Cf. Traité de 1837, art. 8 : "They shall continue to guarantee the Government as before that the rebels of the year 1805 will take no action, direct or indirect, against the whites or any of their property; if such should happen the oath nonetheless, the Aucaners will consider themselves absolved from the oath they have sworn with said rebels, and thereupon do everything in their power to held the whites if they should be so required; and, if the Government sees fit to attack the rebels, the Aucaners shall remain neutral and neither hinder nor help the same; furthermore they will guarantee that no Bonni Maroons shall ever take action against any white or his property, or enter any district of the colony $»$.

Art. 9 : "Likewise they shall undertake, in accordance with the promise they have already made to that effect, to attack, capture and, if necessary, kill any slaves rising on any plantation, or in whatever other place, if so required by the Government; and they shall furthermore at all times prevent such rebellious slaves from mixing with the rebels or Bonni Maroons. » Ibid., p. 69. C'est moi qui souligne.

Les « rebelles de 1805 » sont des « Black Rangers » ou «Black Chasseurs » (esclaves libérés ou auxquels on a promis la liberté, enrôlés en contrepartie pour chasser les esclaves marrons) qui se sont mutinés. Ils seraient à l'origine des Poligodou, distingués par les autorités coloniales des Ndjuka au cours du XIXe siècle, et devenus depuis un clan à part entière des Ndjuka, les Lebimosu. Ibid., notes 57 et 59, p. 110; W. HOOGBERGEN, op. cit., pp. 184-185; F. DUPUY, op. cit., note 63 p. 222. 
merciaux entre les populations situées en amont, Boni, établis sur le Lawa ${ }^{74}$, et Amérindiens, et les populations situées en aval. Ils instaurent pour ce faire un véritable blocus à la confluence.

En 1836, le pharmacien et officier de marine français Leprieur part explorer le sud de la Guyane et se trouve notamment chargé de trouver les sources du Maroni. ${ }^{75}$ Il finit par être accueilli dans le village du Gran Man des Boni, Gongo ; ceux-ci comprennent qu'il a été envoyé par les autorités françaises pour conclure la paix avec eux. Informés, des Ndjuka arrivent et demandent que Leprieur leur soit livré. Les Boni refusent. Leprieur repart à Cayenne accompagné de trois Boni pour négocier la paix avec le gouverneur, et laisse chez les Boni comme otages trois «nègres du roi», des esclaves appartenant à la colonie. Par le biais du posthouder, le Gran Man des Ndjuka, Byman, dénonce le traité qu'aurait signé Leprieur avec les Boni aux autorités coloniales néerlandaises et menace de mort les Français qui viendraient à s'aventurer à nouveau sur le Lawa.

Le gouverneur du Surinam écrit alors au gouverneur de Guyane ${ }^{76}$, Laurens de Choisy, pour protester contre toute négociation de paix avec les Boni : les «Nègres Bonni» ont été «soumis par les Nègres d'Auka» qui les «ont tenus dans un état de dépendance jusqu'à ce moment». C'est la raison pour laquelle «les Nègres d'Auka s'opposent avec tant de zèle à un traité de paix du gouvernement français avec les dits Nègres Bonni sans leur prénotion ou intervention; tandis qu'ils n'approuvent cette démarche sous aucun rapport, ils se tiennent ponctuellement à leur convention avec ce gouvernement, dont ils sont des alliés dépendants». Il conclut en affirmant que des négociations entre les Boni et la France ne pourraient qu'aboutir à une guerre entre Boni et Ndjuka qui menacerait des vies françaises et que «les deux races de nègres (...) reconnaissent le Gouvernement néerlandais comme leur Chef».

74 Probablement vers 1815-1820. F. DUPUY, «Wayana et Aluku», p. 183 et, sur les circuits entre forêt et côte à partir des rapports entre Boni et Amérindiens Wayana (qui présentent des similitudes avec les rapports entre Boni et Ndjuka jusqu'en 1860), cf. pp. 191-193.

Pour un témoignage sur les rapports entre Boni et Ndjuka à la fin des années 1830, Cf. Note sur les nègres Bonis établis sur le Maroni au-dessus du saut d'Itoupoucou par le Commissaire Ordonnateur de la Guyane, 19 mai 1837, J. HURAULT, M. POULIQUEN, op. cit., p. 162. La note s'appuie sur des témoignages directs, ceux de Leprieur (cf. infra) mais aussi du «nègre marron Modeste» qui a séjourné chez les Boni. Le texte est très modéré quant à la «tutelle» Ndjuka : les Boni «n'ont pas de relations immédiates avec les Hollandais; ils reçoivent des nègres Boss des armes et des objets manufacturés en échange des canots qu'ils produisent avec une grande perfection. Les Boss, plus nombreux et mieux armés que les Boni, empêchent ceux-ci de communiquer avec les Hollandais, afin de se réserver tous les avantages du tribut et des échanges. (...) Chaque homme a ordinairement un fusil, mais ces armes sont généralement de mauvaise qualité, parce que les Boss ne se défont que de celles de rebut.»

Les témoignages des posthouder peuvent être contradictoires, l'un d'entre eux estimant en 1846 que les Boni sont en train d'être absorbés par les Ndjuka puis se ravisant par la suite. Cf. S. de GROOT, op. cit., pp. 70-71.

75 Cf. J. HURAULT, « Histoire des Noirs Réfugiés Boni de la Guyane française (d'après les documents de source française) », art. cité, pp. 114-120; T. BELLARDIE, Les Relations entre Français et Bonis en Guyane française, op. cit., p. 34-39; W. HOOGBERGEN, op. cit., pp. 187-190

76 Lettre du Gouverneur de Surinam à M. le Gouverneur de la Guyane française, 28 septembre 1836 (copie). J. HURAULT, M. POULIQUEN, op. cit., p. 138. 
A Cayenne, les trois Boni sont arrêtés puis renvoyés chez eux par le gouverneur qui leur demande de ne pas tenter de communiquer à nouveau avec la Guyane. Il sollicite l'avis du conseil pri$v^{\prime 77}$ : après avoir désavoué Leprieur, le gouverneur indique «qu'il ne pourrait consentir à recevoir en Guyane française une agglomération de révoltés impunis qui seraient pour nos esclaves d'un exemple dangereux.» Il envisage aussi d'envoyer quelqu'un désavouer «le traité» chez les «Auka» si le gouverneur du Surinam y consent. Il est conscient que les Boni sont établis près d'une partie du Maroni «plus avancée dans l'intérieur que les limites auxquelles prétend la Guyane française», «ce qui pourrait faire le sujet de difficultés». Le procureur général Vidal de Ligendes estime que «Si en effet ces noirs sont indépendants, ils ne le doivent qu'à la force et que cette indépendance est par conséquent illégale.» Il considère donc que les «Auka» sont «sujets de la Hollande». Dans sa lettre au gouverneur du Surinam, Le gouverneur de la Guyane désavouera Leprieur tout en insistant sur la souveraineté française sur la rive droite du Maroni. ${ }^{78}$ Informant le ministre, le 15 octobre $1836^{79}$, Laurens de Choisy lui indique que «Ces nègres-Bonni sont (...) sous la dépendance des Auka (...) et tous, quoique révoltés, sont encore les sujets de la Hollande».

Il s'en suivra la signature d'une convention entre les gouverneurs des deux Guyanes datée du 9 novembre 1836, négociée et signée, du côté français, par le procureur général, Vidal de Ligendes ${ }^{80}$. L'article 1er désavoue Leprieur.

Les articles suivants précisent : «Art. 2 : Si des nègres Bonni se présentent sur le territoire français, il leur sera donné connaissance de ce désaveu, et ils seront sommés de se retirer sur le territoire où ils sont tolérés sous la domination des nègres d'Auca. Art. 3 : Le gouvernement de la Guyane hollandaise en faisant connaître aux nègres d'Auca le présent désaveu, leur fera connaître également, ainsi qu'à tous les autres qui sont sous sa domination et qui habitent le Marony que le territoire situé sur la rive droite du Marony à partir de la source de ce fleuve appartient à la France, depuis bien avant qu'ils y fussent établis, que ledit fleuve est la limite entre les deux nations françaises et hollandaises et qu'en conséquence les sujets français ont le droit de passer sur ledit fleuve du Marony. ${ }^{81}$ Le Gouverneur de la Guyane hollandaise enjoindra en conséquence aux nègres dépendant de sa domination et établis sur le Marony de respecter la vie et les propriétés de

77 Extrait du Registre des Procès verbaux des délibérations du Conseil Privé de la Guyane française. Séance extraordinaire du 15 octobre 1836. Ibid., pp. 136-137.

78 Lettre du Gouverneur de Guyane Française au Gouverneur général des possessions néerlandaises en Amérique (copie). Ibid., p. 139.

79 Lettre du Gouverneur au Ministre, 15 octobre 1836, Ibid., p. 135.

80 Convention entre les Gouverneurs des Guyanes hollandaise et française concernant les nègres Bonis. Ibid., p. 217. L'article 4 a une portée plus limitée, quoique symbolique : «Le Gouvernement de Surinam fera réclamer 3 nègres français qui ont été laissés en otage chez les Bonis en échange de 3 Bonis qui ont accompagné Le Prieur, puis ont été renvoyés dans leur pays. Le gouvernement hollandais rendra a celui de la Guyane française les trois otages.»

81 Cet article 3 est tronqué dans le recueil de J. HURAULT et M. POULIQUEN, qui restitue la copie de la convention provenant du ministère des affaires étrangères. Je le restitue dans son intégralité à partir d'une copie des trois premiers articles de la convention datant de 1860 : Extrait d'une convention entre les Guyanes française et hollandaise, trouvée dans les archives de Mana, ANOM, FM, SG, GUY39, Dossier D3 (01). 
tout Français qui passera sur ce fleuve, sauf, si quelque Français pouvait être la cause de quelque trouble à le conduire à Paramaribo afin qu'il en soit référé aux deux gouvernements. »

Le texte sera approuvé par le ministère des colonies et par le ministère des affaires étrangères en $1837 .^{82}$

Le nouveau traité de paix entre les autorités néerlandaises et les Ndjuka, ratifié en 1837 par les autorités coloniales mais signé au début de l'année $1836^{83}$, n'affirme pas, quant à lui, de domination des Ndjuka sur les Boni : les premiers doivent empêcher les seconds d'attaquer les blancs et leurs propriétés, mais aussi empêcher d'accéder à « tout district de la colonie » du Surinam ${ }^{84}$. Or, à l'époque, les Néerlandais sont convaincus que le Tapanahoni constitue le cours supérieur du Maroni $^{85}$ (ce qui n'est pas le cas) : dans cette perspective, les Ndjuka, établis sur le fleuve, empêchent les Boni, établis sur un affluent situé en pleine Guyane française, le Lawa, d'accéder au Surinam.

Alors que les nouveaux traités de paix interdisent notamment aux « Marrons pacifiés » d'entrer en relation avec un pouvoir étranger, la convention franco-néerlandaise de 1836 renforce de toute évidence la position des autorités du Surinam. Refusant de reconnaître directement les peuples marrons et donc de négocier avec eux ${ }^{86}$, la France ne fait qu'entériner le discours que lui a tenu le gouverneur néerlandais : les «nègres d'Auca», comme les autres «marrons pacifiés», sont sous la domination du «gouvernement de la Guyane hollandaise». Et comme les «nègres Bonni» sont sous la domination des «nègres d'Auka», ils sont indirectement sous la domination du gouvernement du Surinam. De plus, le gouverneur du Surinam parvient à réaliser ce qui n'avait jamais été réussi lors des guerres boni : impliquer le pouvoir colonial français dans la répression des Boni. Désormais, le blocus ndjuka se voit complété par un blocus français ${ }^{87}$ empêchant les Boni d'accéder à la côte guyanaise. De fait, la convention de 1836 paraît emprunter aux nouveaux traités de paix que les Pays-Bas sont en train de conclure avec les trois peuples marrons " pacifiés » l'idée de cantonnement- sauf que les Boni se voient strictement interdire toute sortie du territoire sur lequel ils sont tenus de rester : ils ne doivent pas se présenter sur le «territoire français » mais demeurer «sur le territoire où ils sont tolérés sous la domination des nègres d'Aucas».

82 Convention entre les Gouverneurs des Guyanes hollandaise et française concernant les nègres Bonis. J. HURAULT, M. POULIQUEN, op. cit., p. 217.; résumé des lettres du Ministre de la Marine et des Colonies au Ministre des Affaires étrangères, 13 septembre 1837, et du Ministre de la Marine et des Colonies au Gouverneur de Guyane, Ibid., p. 152.

83 E.-R. KAMBEL, F. MacKAY, op. cit., note 46 p. 77. Le processus de ratification est assez complexe : Ibid., p. 65.

84 Cf. supra.

85 S. de GROOT : op. cit.; p. 70.

86 Les Français considèrent en effet que les Hollandais ont reconnu l'indépendance des Ndjuka, et insistent sur ce fait à plusieurs reprises. C'est bel et bien le refus de reconnaitre cette «indépendance» qui incite les Français à ne traiter qu'avec les Pays-Bas. Cf. supra.

87 Les Amérindiens son invités à participer à ce blocus : le 6 juin 1837, le Conseil privé décide que «les Indiens recevront une récompense proportionnée généreusement aux services qu'ils rendront en cas d'hostilités avec les Boni». Extrait des procès-verbaux des délibérations du Conseil privé de la Guyane- 6 juin 1837. Ibid., p.163. 
La France entérine la présence des Ndjuka, rattachés aux Pays-Bas, sur les deux rives du Maroni. Dans le même temps, la souveraineté française sur la rive droite du Maroni jusqu'à la source du fleuve est reconnue et le principe de la liberté de navigation et de circulation est affirmé pour les Français. Les Ndjuka doivent respecter " la vie et la propriété » des Français comme ils doivent respecter celle des Blancs au Surinam.Toutefois, en cas de trouble causé par un Français, les Ndjuka doivent l'amener à Paramaribo pour en référer aux deux gouvernements. Mais la France n'a alors aucun établissement sur le fleuve.

Les Boni se retrouvent ainsi enfermés dans une situation singulière : du côté du Surinam, on ne veut envisager de traité de paix, et par là même la reconnaissance de l'autonomie et de la liberté ; du côté de la Guyane, on les renvoie à la domination indirecte du Surinam. Les deux puissances coloniales s'accordent pour considérer qu'ils sont placés sous la domination des Ndjuka - ou plus exactement que les questions les concernant relèvent avant tout de la compétence des Ndjuka.

Les autorités françaises paraissent ainsi privilégier leurs préjugés esclavagistes par rapport à leurs intérêts stratégiques : la frontière du Maroni est confirmée, mais les autorités françaises préfèrent reconnaître une forme de domination des Pays-Bas sur le fleuve via leur domination supposée sur les Ndjuka plutôt que de négocier directement avec ce peuple marron. Le gouverneur du Surinam ne se privera pas de constater ironiquement la situation dans laquelle se sont placées les autorités françaises ${ }^{88}$ : "Quoique les Nègres Boni aient reconnu l'autorité du gouvernement hollandais, cette autorité n'est pas dans le sens propre par nous directement exercée, mais seulement par l'intermédiaire des aukaniers qui nous sont soumis : cela est d'autant plus vrai quand on prend en considération que les nègres Boni sont de fait établis sur l'autre rive de la Maronyne, et cela conformément à la convention conclue au nom de Votre Excellence avec le sieur Vidal de Ligendes, par laquelle cette contrée doit être considérée comme faisant partie du territoire français... Il doit être déduit que mon autorité ne s'étende pas au delà de l'autre rive de la Maronyne, Votre Excellence remarquera alors elle-même combien il m'est difficile d'entrer directement dans ces difficultés...»

La suite des évènements sera dans un premier temps dramatique : pour contourner le blocus ndjuka, les Boni «tentent de trouver un exutoire vers la côte en empruntant l'Approuage et surtout l'Oyapock». ${ }^{89} \mathrm{Il} \mathrm{s}$ 'en suivra des affrontements avec différents peuples amérindiens (Emerillons, Wayapi notamment) et avec les Français dans la région de l'Oyapock : quatre Boni sont exécutés sommairement en 1837 (ce qui entrainera la destitution du gouverneur Laurens de Choisy) et, en 1841, une petite colonie boni qui s'est établie sur une petite île et qui comprend le Gran Man Gongo est décimée, en partie accidentellement (d'après le rapport officiel), par un détachement de militaires et d'Amérindiens sur la base d'accusations d'Améridiens. ${ }^{90}$

88 Lettre du gouverneur du Surinam au gouverneur de la Guyane française, 12 juin 1837 (copie), Ibid., p. 150.

89 F. DUPUY,«Wayana et Aluku», p. 183.

90 J. HURAULT, « Histoire des Noirs Réfugiés Boni de la Guyane française», pp. 118-125; T. BELLARDIE, op. cit., pp. 40-49 ; S. de GROOT, art. cité, p. 47; P. GRENAND, op. cit., pp.310-311, p. 216; P. GRENAND, F. GRENAND, "L'occupation amérindienne : ethnoarchéologie, ethnohistoire », art. cité, p. 68; W. HOOGBERGEN, op. cit.,pp. 190-195 et art. cité, p 139. 
Les Boni avaient pourtant exprimé clairement leur souhait de conclure un traité avec les Français en 1839, lors d'une rencontre entre le commandant du poste de Cafesoca et six d'entre-eux ${ }^{91}$. Très schématiquement, les Boni proposent de ramener les esclaves évadés pour obtenir en échange des « cadeaux » composés de bien manufacturés. ${ }^{92}$

Mais après le drame de 1841, les Boni ne tenteront plus d'avoir des contacts avec les Français et demeureront sur le Lawa.

La période 1836-1841 voit ainsi deux grands vainqueurs : les autorités néerlandaises et les Ndjuka. Alors que la Monarchie de Juillet est engagée dans une politique tendant à améliorer le sort des esclaves et a aboli le préjugé de couleur en 1833, les autorités françaises en Guyane consentent quant à elles à se faire manipuler dès lors que les propos tenus sur les Boni vont dans le sens des préjugés esclavagistes : les on-dit défavorables aux Boni sont systématiquement privilégiés par rapport aux témoignages directs, beaucoup plus favorables ou modérés. Les Boni, quant à eux, sont, pour les autorités coloniales (d'un point de vue franco-néerlandais plus que d'un point de vue néerlandais), placés directement sous l'autorité des Ndjuka, et sous la domination néerlandaise par la médiation de ces derniers. Peu nombreux d'après tous les témoignages (quelques centaines d'individus), leur problème est qu'ils ont cessé de représenter une menace militaire suffisante pour motiver un traité de paix ${ }^{93}$, tout en demeurant une menace symbolique pour l'ordre esclavagiste ${ }^{94}$, traumatisé par la première abolition et par l'indépendance de Haïti, dont les Marrons du Surinam peuvent paraître rétrospectivement un signe annonciateur. Si le pouvoir colonial s'est bel et bien résigné au fait marron, si le phénomène lui fait moins peur ${ }^{95}$, il ne conçoit pas non plus de signer la paix dès lors que ce n'est pas militairement nécessaire. Or les Ndjuka empêchent les Boni d'accéder à des armes dignes de ce nom.

En 1848, la France ne cherchera pas à informer les Boni qu'elle vient d'abolir l'esclavage et que le sol de la Guyane française, désormais, affranchit tout esclave qui le foule ${ }^{96}$. C'est, plus tardivement, le développement de la présence française sur le Maroni et surtout la perspective de

91 D'après le rapport, les Boni proposent de se placer sous «la protection du Gouvernement français», de s'établir loin du poste, de commercer avec les Français en leur fournissant divers produits en échange de produits manufacturés, notamment d'armes. Enfin, ils s'engagent quoiqu'il en soit à ramener les esclaves qui se réfugieraient chez eux.

Rapport du commandant du poste de Cafésoca au sujet de son entrevue avec 6 Boni le 1er juin 1839, daté du 7 juin 1839 in J. HURAULT, M. POULIQUEN, op. cit., p. 173.

$92 \mathrm{Cf}$. en ce sens, ibid. et Note sur les nègres Bonis établis sur le Maroni au-dessus du saut d'Itoupoucou par le Commissaire Ordonnateur de la Guyane, 19 mai 1837 in J. HURAULT, M. POULIQUEN, op. cit., p. 146 : «Ces noirs conçurent dès lors l'espoir d'établir des relations avec les Français afin d'obtenir des armes, des munitions et des objets manufacturés en retour de la capture des marrons des établissements de la frontière française».

93 Cf. en ce sens S. de GROOT, op. cit., p. 70.

94 Je met ici de côté le climat de psychose des années 1836-1837, ouvert par l'arrivée de Leprieur à Cayenne et clos par l'exécution sommaire qui allait aboutir au limogeage du gouverneur Laurens de Choisy.

95 S. de GROOT, op. cit., p. 70.

96 Décret du 27 avril 1848 relatif à l'abolition de l'esclavage dans les colonies et les possessions françaises, art. 7 : «Le principe que le sol de la France affranchit l>esclave qui le touche est appliqué aux colonies et possessions de la République.» 
l'abolition de l'esclavage au Surinam qui permettront aux Boni de commencer à tisser un lien direct avec la France.

\section{II ...AU LIEN DIRECT AVEC LA FRANCE}

Les traités de paix avec les Marrons sont profondément liés à l'ordre esclavagiste : dès lors que l'esclavage est aboli, dès lors que la liberté est devenue générale, ils ne sont plus nécessaires. Les Boni vont se trouver dans un entre-deux : lorsqu'en 1860 Néerlandais et Français viennent leur annoncer leur «libération», l'esclavage est aboli en Guyane, mais devra attendre 1863 pour l'être au Surinam. Si l'intérêt que leur témoignent désormais les autorités des deux colonies est avant tout motivé par un but migratoire tout en étant en partie lié à la question frontalière, c'est à la fin des années 1870 que le lien entre les Boni et la France commence à se formaliser, jusqu'à ce qu'il soit définitivement confirmé à la faveur d'un arbitrage frontalier. C'est après avoir vu les deux puissances se présenter comme libératrices, que les Boni choisiront de construire un consensus avec la seule France.

\section{A. LA RECONNAISSANCE NÉERLANDAISE ET LA CONFIRMATION FRAN- ÇAISE DE LA LIBERTÉ}

En 1860, les Ndjuka continuent d'exercer leur blocus à la confluence entre le Lawa et le Tapanahoni et d'importuner les voyageurs ou exploitants français. Les Français sont désormais présents sur le Maroni : le bagne de Saint-Laurent-du-Maroni a été créé en 1858, de plus en plus de Français s'installent dans la région. Les Boni quant à eux ont commencé à commercer avec la côte par le biais d'un exploitant forestier et aventurier nommé Tollinche, très présent dans la mémoire boni. Le rôle de Tollinche paraît essentiel dans la naissance du lien des Boni avec la France : grâce à lui, ils ont commencé à échapper au blocus des Ndjuka. Rencontrant l'hostilité de ces derniers, il attire l'attention des autorités françaises sur la situation des Boni, tout en montrant le problème posé par le verrou ndjuka. ${ }^{97}$ Il devient par ailleurs clair que l'esclavage sera bientôt aboli au Surinam, où les « Marrons pacifiés » voient les principales restrictions à leur accès à la côte levées en $1856 .{ }^{98}$

Du fait de l'abolition de l'esclavage, la dimension anti-Boni de la convention de 1836 est désormais sans objet du côté français : il devient concevable de traiter avec des peuples marrons.

97 Rapport d'un voyage fait en novembre 1860 au haut du Maroni, chez les nègres Bosch et Bonis, par M. Ronmy, lieutenant de l'Etat-major de l'infanterie de marine, 4 janvier 1861, ANOM, FM, SG, GUY39, Dossier D3 (01).

Rapport d'un voyage fait en novembre 1860 au haut du Maroni, chez les nègres Bosch et Bonis, par M. Ronmy, lieutenant de l'Etat-major de l'infanterie de marine (extraits), 4 janvier 1861, J. HURAULT, M. POULIQUEN, op. cit., p. 190. De larges extraits de ce rapport sont publiés dans RONMY,«Excursion dans le haut Maroni (Guyane française) », Revue maritime et coloniale, t.1, 1861, p. 779-796 (repris et annoté dans F. DUPUY, op. cit., pp. 207-230).

A propos de Tollinche, qui donnera son nom à un des Gran Man des Boni, Tollinga, cf. T. BELLARDIE, op. cit., p. 54; F. DUPUY, op. cit., note 5, p. 196.

98 Cf. supra. 
Mais le texte garde par contre toute sa pertinence quant à la libre circulation sur le Maroni99. En juillet 1856, le Gouverneur de la Guyane française, Bondin, avait rencontré à Albina le Gran Man des Ndjuka, Byman, chez l'assistant du posthouder auprès des Ndjuka, August Kappler. Bondin avait indiqué à Kappler qu'il souhaitait que les Boni, établis en territoire français, puissent accéder au Bas Maroni pour pouvoir y vendre leurs produits ou travailler, ce qui devrait favoriser le développement des établissements européens situés sur les deux rives. ${ }^{100}$ Le Gouvernement du Surinam donna des instructions au Gran Man Byman allant dans ce sens, mais elles ne furent pas suivies d'effet, et les Ndjuka continuèrent de mener leur stratégie d'obstruction à l'égard des Français. ${ }^{101}$

Les Néerlandais comprennent que la situation n'est plus acceptable : l'irritation française vis-à-vis des Ndjuka, la situation de Boni liés aux Pays-Bas sur un Lawa que l'on croit alors en territoire français, appellent une solution. Il y a un consensus franco-néerlandais pour faire émigrer les Boni sur la côte, mais chaque puissance espère qu'ils iront travailler dans ses propres établissements. Pour cela, il faut mettre fin au verrou ndjuka. ${ }^{102}$ Ce sera fait entre août et novembre 1860 , lors de divers épisodes qui voient Français et Néerlandais coopérer tout en se faisant concurrence, avec la part de non-dits et de faux-semblants que cela peut impliquer. ${ }^{103}$

En août 1860, le Gouverneur de la Guyane française, Tardy de Montravel, rencontre le Gouverneur de la Guyane néerlandaise, Van Lansberge, à l'occasion d'une tournée sur le Maroni ${ }^{104}$. Les deux hommes se mettent d'accord d'une part pour mettre en place une petite expédition franco-néerlandaise auprès des Ndjuka pour qu'ils laissent les "Bonis et autres tribus sur le fleuve » circuler librement et d'autre part pour proposer à leurs autorités respectives la mise en place d'une

99 Le lien avec la convention de 1836 est clairement établi par Ronmy qui, après avoir résumé le texte, indique : "Cette convention, valable en 1836, n'était plus en concordance avec l'émancipation de 1848, aussi était-elle tombée en oubli, par le peu de mouvement de la population riveraine, lorsque le gouvernement juge convenable d'établir la transportation au Maroni». Rapport d'un voyage fait en novembre 1860 au haut du Maroni, chez les nègres Bosch et Bonis, par M. Ronmy, lieutenant de l'Etat-major de l'infanterie de marine, 4 janvier 1861, ANOM, FM, SG, GUY39, Dossier D3 (01).

100 S. de GROOT, op. cit., pp. 71-73.

101 Ibid., pp. 73-74.

102 Ibid., p. 74.

103 Pour l'aspect néerlandais, cf. surtout Ibid., pp. 74-81. Cf. aussi W. HOOGBERGEN, op. cit., pp. 196198; E.-R. KAMBEL et F. MacKAY, op. cit., pp. 60-61; K. BILBY, «Swearing by the Past, Swearing to the Future», art. cité. Pour l'aspect français, je m'appuie surtout sur les archives du ministère chargé des colonies (ANOM, FM, SG, GUY39, Dossier D3 (01)). Cf. T. BELLARDIE, op. cit., pp. 49-67; F. DUPUY, op. cit., pp. 193-230.

104 Lettre du Gouverneur de la Guyane française au Ministre de l'Algérie et des colonies du 3 septembre 1860, ANOM, FM, SG, GUY39, Dossier D3 (01).

Lettre du Gouverneur du Surinam Van Lansberge au Gouverneur de la Guyane française Tardy de Montravel, du 24 juillet 1861 (AD Guyane, X388). Cette lettre confirme l'existence de faits qui ne sont pas mentionnés dans les travaux s'appuyant sur les archives du Surinam (S. de GROOT, op. cit.), et notamment de cette rencontre. 
commission franco-néerlandaise tendant à déterminer quel cours d'eau, le Tapanahoni ou le Lawa, constitue le cours supérieur du Maroni. ${ }^{105}$

Une rencontre entre les Gouverneurs des deux Guyane et le Gran Man ndjuka Byman est également prévue mais, ne pouvant attendre, Tardy de Montravel rentre à Cayenne et donne des instructions à son chef d'état-major, Sibour, pour le représenter. ${ }^{106}$ Byman arrive le 7 septembre à Albina. La rencontre a lieu le 8 septembre, après que le Gran Man se soit entretenu avec le gouverneur néerlandais : Van Lansberge et Sibour indiquent au Gran Man que la domination ndjuka sur les Boni (et sur les «tribus indiennes de l'intérieur ») n'a pas lieu d'être et qu'ils doivent donc les laisser circuler et émigrer librement sur le Bas Maroni; plus largement ils doivent mettre fin à leur attitude à l'égard des Français. ${ }^{107}$ Le Gouverneur néerlandais s'en va le jour même et à partir du 9 septembre, Sibour négocie avec Byman sur la rive française. Le « traité d'amitié » franco-ndjuka est conclu le 11 septembre. Les autorités néerlandaises ont donc aidé les Français à conclure un accord avec les Ndjuka alors que ces derniers n'ont en principe pas le droit de traiter avec une puissance étrangère et alors que les Français souhaitent également recourir à une main d'oeuvre ndjuka et attirer leur commerce ${ }^{108}$. Mais les Néerlandais croient que les Ndjuka sont établis sur le cours principal du fleuve, qu'il s'agisse du Haut Maroni ou du Bas Maroni : il faut donc, d'une manière ou du autre, régler la question de ceux établis sur la rive française (ou supposée telle). ${ }^{109}$

Tardy de Montravel s'est engagé, en contrepartie, comme son prédécesseur, à laisser les Boni émigrer, s'ils le souhaitent, du côté du Surinam. Le 20 octobre 1860, le Gouverneur Van Lansberge annonce au Conseil colonial ${ }^{110}$ qu'il va envoyer sur le Haut Maroni une petite commission (composée d'un membre du Conseil colonial, F. S. Eyken Sluyters, et de l'Inspecteur des terres de la Couronne, de l'industrie et de l'agriculture H. C. J. Slengarde). Elle doit annoncer aux Boni que, désormais, ils seront soumis aux mêmes règles et bénéficieront des mêmes privilèges que

105 Lettre du Gouverneur de la Guyane française au Ministre de l'Algérie et des colonies du 3 septembre 1860, ANOM, FM, SG, GUY39, Dossier D3 (01).

106 Ibid. Lettre du Gouverneur de la Guyane française au Ministre de l'Algérie et des colonies du 28 septembre 1860, ANOM, FM, SG, GUY39, Dossier D3 (01).

Tardy de Montravel insiste sur le fait que Sibour avait assisté avec lui « en Chine et au Japon à plusieurs entrevues du même genre ». Ibid.

107 Rapport de Sibour au gouverneur de la Guyane sur sa mission chez les nègres Bosch du 24 septembre 1860, Ibid. De larges extraits sont publiés dans Lieutenant de Vaisseau SIBOUR, «Nos relations avec les nègres et les indiens du Haut-Maroni», Revue maritime et coloniale, t.1, 1861, pp. 117-129 (repris et annoté dans F. DUPUY, op. cit., pp. 193-206).

S. de GROOT, op. cit., p. 74.

Lettre du Gouverneur du Surinam Van Lansberge au Gouverneur de la Guyane française Tardy de Montravel, du 24 juillet 1861 (AD Guyane, X388).

108 Lettre du Gouverneur de la Guyane française au Ministre de l'Algérie et des colonies du 28 septembre 1860, ANOM, FM, SG, GUY39, Dossier D3 (01).

109 Ibid.

S. de GROOT, op. cit., p. 75.

110 Crée en 1832, composé du procureur général et de six représentants des planteurs, le Conseil colonial témoigne de cette " plantocratie » propre à cette colonie néerlandaise. Ibid., pp. 4-5. 
les « Marrons pacifiés »; en conséquence, ils ne seront plus sous la sujétion des Ndjuka, mais au contraire placés sur un pied d'égalité avec ces derniers. Elle doit annoncer aux Ndjuka qu'ils sont relevés de toutes leurs responsabilités à l'égard des Boni et qu'ils ne doivent donc plus les placer en sujétion. Elle doit inviter Boni et Ndjuka à s'établir dans les parties cultivées de la colonie. Enfin,de manière plus officieuse, elle devra commencer à étudier les cours des Maroni, Tapanahoni et Lawa. ${ }^{111}$ Le Gouverneur Tardy de Montravel charge quant à lui le commandant du bagne de Saint-Louis, Ronmy, de se joindre à l'expédition néerlandaise pour faire appliquer les accords conclus avec les Ndjuka, ce qui implique d'annoncer également la nouvelle situation aux populations qui ne pouvaient accéder à la côte; de les inviter à émigrer vers la zone côtière et de préparer la route que devrait emprunter la future commission chargée de déterminer le cours supérieur du fleuve. ${ }^{112}$

L'expédition, du 29 octobre au 25 novembre 1860, dure un mois ${ }^{113}$. La rencontre avec les Boni a lieu les 17 et surtout 18 novembre et donne l'occasion aux Français (Tollinche est présent) et aux Néerlandais de réaliser leurs projets : les Néerlandais concluent un « traité de paix » avec les Boni ${ }^{114}$, les Français comme les Néerlandais croient rencontrer une réponse positive des Boni à leurs propositions d'émigration ${ }^{115}$. Mais les mesures réalisées par Eyken Sluyters et Slengarde montrent que c'est le Lawa qui constitue le cours supérieur du Maroni1"16, ce qui sera confirmé en 1861. Dès lors, s'agissant des Boni et des Ndjuka, les rapports franco-néerlandais se tendent : l'attitude particulièrement conciliante des Néerlandais s'expliquait par leur croyance en un Lawa en plein territoire français.

\section{Ibid., pp. 74-75.}

112 Lettre du Gouverneur de la Guyane française au Ministre de l'Algérie et des colonies du 28 septembre 1860, ANOM, FM, SG, GUY39, Dossier D3 (01).

Lettre du Gouverneur de la Guyane française au Ministre de la Marine et des colonies du 7 janvier 1861, Ibid.

Lettre du Gouverneur de la Guyane française au Ministre de la Marine et des colonies du 30 janvier 1861, Ibid.

Rapport d'un voyage fait en novembre 1860 au haut du Maroni, chez les nègres Bosch et Bonis, par M. Ronmy, lieutenant de l'Etat-major de l'infanterie de marine, 4 janvier 1861, Ibid.

113 Pour le point de vue français, Ibid; pour le point de vue néerlandais, cf. S. de GROOT, op. cit., pp. 7578.

114 E.-R. KAMBEL et F. MacKAY, op. cit., pp. 60-61. Le texte du traité figure en annexe du rapport de F. S. Eyken Sluyters et de H. C. J. Slengarde. Ibid., note 52 p. 77.

115 Rapport d'un voyage fait en novembre 1860 au haut du Maroni, chez les nègres Bosch et Bonis, par M. Ronmy, lieutenant de l'Etat-major de l'infanterie de marine, 4 janvier 1861, ANOM, FM, SG, GUY39, Dossier D3 (01).

S. de GROOT, op. cit., p. 77.

116 Ibid., p. 75. Ronmy ne conteste pas ce constat d'après le rapport des Néerlandais, mais l'intéressé continue d'affirmer que le territoire est français dans son propre rapport : Rapport d'un voyage fait en novembre 1860 au haut du Maroni, chez les nègres Bosch et Bonis, par M. Ronmy, lieutenant de l'Etat-major de l'infanterie de marine, 4 janvier 1861, ANOM, FM, SG, GUY39, Dossier D3 (01). 
Il n'en demeure pas moins que ce second semestre de l'année 1860 aura vu se développer deux conceptions juridiques différentes : si les Pays-Bas peuvent continuer de faire une lecture des traités de paix allant dans le sens d'une subordination des «Marrons pacifiés» à leur autorité, la France, pour pouvoir négocier directement avec ces derniers, ne peut qu'affirmer qu'ils sont indépendants ${ }^{117}$.

L'accord conclu par la France avec les Ndjuka est donc fondamental pour comprendre les principes qui vont régir les relations entre la France et les peuples marrons des Guyanes, mais il contraste singulièrement avec l'absence d'accord conclu par la France avec les Boni.

\section{L’ACCORD CONCLU PAR LA FRANCE AVEC LES NDJUKA}

On a vu que les Néerlandais avaient aidés les Français à conclure cet accord avec les Ndjuka: après une rencontre à Albina entre le Gouverneur du Surinam, le chef d'état major du Gouverneur de la Guyane et le Gran Man des Ndjuka le 8 septembre 1860, les Français négocient séparément avec les Ndjuka à partir du 9 septembre, et concluent avec eux, le 11 septembre 1860, des «arrangements» ${ }^{118}$ signés au pénitencier de Saint Louis, et qui seront par la suite approuvé par Tardy de Montravel.

Le texte est la première convention conclue par la France avec un peuple marron et la place des Boni y est minime : ils sont juste mentionnés dans l'article 1er. Le texte, de par son importance, n'en doit pas moins être reproduit dans son intégralité :

«Art. 1er. Le Grand Man Byman, éclairé par S.E. le gouverneur de la Guyane hollandaise en séance publique et en présence de ses capitaines, reconnaît l'entière liberté du fleuve Maroni comme de ses affluents ; c'est à dire qu'à partir de ce jour, 8 septembre $1860^{119}$, toute personne appartenant à quelque nation, tribu, peuplade que ce soit, Française, Auca, Bonie, Roucouienne, etca, peut remonter ou descendre le Maroni ou ses affluents pour raison de commerce ou toute autre sans que nul n'y puisse porter le moindre empêchement ou obstacle.

Art. 2. Le Grand man Gouverneur des Aucas reconnaissant des assurances de bon voisinage données au nom de S.E. le gouverneur de la Guyane française s'engage dans la mesure de ses forces et de son autorité à accorder aide et protection à tout sujet français ou allié, séjournant ou voyageant sur les terres où il commande et, en réciprocité, aide et protection sont garanties à tout Auca ou allié des Aucas voyageant et séjournant sur les terres soumises à la domination française.

Art. 3. Le gonflement ${ }^{120}$ en usage jusqu'à ce jour ne pourra plus être pour les Français qu'une épreuve librement consentie puisque, à partir de ce jour, S.E. le gouverneur de Cayenne entrant en

\section{Cf. infra.}

118 Arrangements convenus et librement consentis de part et d'autre entre le Grand man Byman chef des Nègres Bosch Aucas et Monsieur Sibour, lieutenant de vaisseau, chef d'état-major de S.E. le Gouverneur de la Guyane française et son fondé de pouvoir (copie). ANOM, FM, SG, GUY39, Dossier D3 (01).

119 L'arrangement est bel est bien antidaté : le rapport de Sibour date sa signature du 11 septembre, mais la date indiquée par l'article 1er est celle de la réunion avec le gouverneur du Surinam.

120 «En termes bushinenge, il s'agit du sweli, notion polysémique qui signifie globalement un pacte, un serment, une épreuve, placés sous ce qu'il y a de plus sacré et dont on ne peut se dédire sans encourir la sanction suprême infligée par les divinités ou les ancêtres. Dans les cas extrêmes ou lors de l'interrogatoire 
relations amicales avec le Grand man des Aucas se charge de sévir suivant nos lois, contre tout sujet Français ou protégé qui se rendrait coupable d'un méfait quelconque vis-à-vis du Grand man ou de l'un de ses sujets, tout comme le Grand man aurait à sévir contre tout Auca qui se rendrait coupable d'un méfait quelconque vis-à-vis d'un sujet Français ou protégé de la France.

Art. 4. De part et d'autre des relations commerciales seront favorisées autant que possible.

Art. 5 . Pour preuve de son bon vouloir et de ses intentions amicales, chaque fois qu'il aura pu être prévenu, le Gran man enverra auprès des voyageurs officiels se rendant auprès de lui, des guides et des canots.

Art. 6. Le Gran man des Aucas étant l'ami du Gran man Français, il sera accordé une prime de 20 francs pour tout transporté déserteur de nos établissements pénitentiaires capturé et ramené sur un de ces établissements.»

Les autorités coloniales publieront le texte dans la Feuille de la Guyane française, le supplément pour la Guyane du Moniteur universel... mais dans sa partie non officielle ${ }^{121}$ : reprenant la publication issue du rapport de Sibour, déjà parue dans la Revue maritime et coloniale, elles laissent figurer le traité en note en bas de page, amputé de son article 6. Mais les Français ne s'en considèrent pas moins liés par le texte : Tardy de Montravel transforme l'article 6, seule disposition à portée financière, en décision publiée quant à elle au Bulletin officiel de la colonie ${ }^{122}$.

Le Gouverneur français sollicite par ailleurs l'assentiment du ministre pour cette convention qui, renversant la «barrière élevée par les Awcas », le " rapproche d'une réussite complète » tout en précisant que «le Gran-man, semblable en cela aux Mandarins chinois ou japonais et à tous les chefs de tribus sauvages, ne se considérera lié par son engagement que quand il sera mis en demeure de le remplir ${ }^{123}$. Ce sera un des objectifs de Ronmy en novembre 1860 . L'existence de la

post mortem, il s'agit ni plus ni moins que d'une ordalie. Le sweli est aussi l'obia (force magico-religieuse) le plus puissant associé au gran man. »(F. DUPUY, op. cit., note 24, p. 205). C'est le sweli comme serment qui est visé ici : les deux protagonistes se font saigner. On recueille quelques gouttes de sang dans une calebasse, que l'on mêle à une boisson, que l'on boit.

Pour une approche plus développée, qui est aussi une approche anthropologique de la conclusion des traités par les Marrons de la Jamaïque et des Guyanes avec les autorités coloniales, cf. K. BILBY, «Swearing by the Past, Swearing to the Future», art. cité.

121 Moniteur universel. Journal officiel de l'Empire français. Feuille de la Guyane française. № 18.4 mai 1861 .

122 Décision qui fixe la prime de capture des transportés évadés à l'égard des nègres awcas, 21 août 1861, BOGF $1861, \mathrm{n}^{\circ} 329, \mathrm{p} .328$. Elle débute ainsi : «conformément à la convention conclue, le 8 septembre 1860, avec le chef des nègres awcas».

123 Lettre du Gouverneur de la Guyane française au Ministre de l'Algérie et des colonies du 28 septembre 1860, ANOM, FM, SG, GUY39, Dossier D3 (01).

Une copie de la convention sera également transmise au ministère des affaires étrangères.

Cf. Arrangements convenus et librement consentis de part et d'autre entre le Grand man Byman chef des Nègres Bosch Aucas et Monsieur Sibour, lieutenant de vaisseau, chef d'état-major de S.E. le Gouverneur de la Guyane française et son fondé de pouvoir (copie), Ibid. sur lesquels sont annotés au crayon : «fait copie pour les affaires étrangères ». 
convention franco-ndjuka et son application pourront également produire par la suite une certaine irritation du coté néerlandais. ${ }^{124}$

Si les autorités françaises ne paraissent pas reconnaître de valeur juridique à cet accord, elles se considèrent de toute évidence comme politiquement liées.

Ceci rend ces « arrangements » d'autant plus précieux : ils rendent lisibles les principes qui sous tendent les pratiques qui vont régir, de fait, la situation des peuples marrons en Guyane française.

Le paradoxe apparent de ce texte lié à la volonté de la France de voir sa souveraineté devenir effective sur la rive droite d'un Maroni dont le Tapanahoni serait le cours supérieur, est qu'il reconnaît aux Ndjuka le statut d'entité politique indépendante. Les propos de Tardy de Montravel sont clairs : il évoque les " tribus Boschs, Bonis et autres qui habitent le haut du Maroni et les bords de ses affluents supérieurs, tribus qui, pour la plupart, sont liées par des conventions avec le gouvernement hollandais » et qualifie les Ndjuka de «tribu indépendante $» .{ }^{125} \mathrm{Ce}$ discours prend entièrement le contrepied de la reconnaissance d'une domination néerlandaise sur les peuples marrons en 1836 : cette fois, il leur arrive juste d'être liés par des conventions avec les Pays-Bas, comme n'importe quel Etat indépendant, ce qui ne les empêche donc pas de conclure des conventions avec les gouvernements d'autres Etats.

La finalité pratique de cette conception ne fait guère de doute : c'est le seul moyen pour la France de justifier le fait qu'elle traite directement avec les peuples marrons, au lieu de traiter avec les seules autorités néerlandaises, comme elle l'avait fait auparavant. Mais elle formule aussi les pratiques existantes à l'égard des peuples amérindiens, dont les autorités françaises sont plus familières : les "tribus indépendantes » ne sont pas seulement marrons, c'est la seule situation particulière des Ndjuka qui appelle la conclusion d'une convention écrite. S'agissant de ces derniers, cette conception entérine aussi, tout simplement, un rapport de force : les Français ont pu constater la réalité de la puissance ndjuka sur le Maroni et le caractère tout relatif de l'autorité que les Néerlandais prétendaient exercer sur eux.

Elle traduit également les ambitions françaises à l'égard des Ndjuka, que Tardy de Montravel résume ainsi à son ministre de tutelle : "Quant aux Bosch, il ne sera sans doute pas difficile de leur faire comprendre qu'ils ont intérêt à profiter de notre voisinage pour se procurer chez nous les denrées et marchandises qu'ils vont, à grande perte de temps, chercher jusqu'au Surinam. Je ne doute pas que le Gouvernement colonial hollandais ne cherche à conserver le monopole du commerce de cette population et même à la faire émigrer vers le centre de sa production en prévision de l'émancipation prochaine des esclaves mais je doute qu'il y réussisse et je compte même sur l'esprit mercantile des Bosch pour les rapprocher progressivement de nous ». ${ }^{126}$

On voit ainsi se dessiner ce que qui sera la ligne des autorités françaises : considérer les peuples marrons comme des «tribus indépendantes», leur reconnaître en conséquence une plus grande

124 S. de GROOT, op. cit., pp. 78-79.

125 Lettre du Gouverneur de la Guyane française au Ministre de l'Algérie et des colonies du 3 septembre 1860, ANOM, FM, SG, GUY39, Dossier D3 (01).

126 Lettre du Gouverneur de la Guyane française au Ministre de l'Algérie et des colonies du 28 septembre 1860, ANOM, FM, SG, GUY39, Dossier D3 (01). 
autonomie qu'au Surinam, ce qui peut être une manière d'être attractif en terme migratoire, mais aussi de conclure des accords avec les Gran Man concernant la main d'oeuvre marron, avec leurs règles propres ${ }^{127}$.

Cette «indépendance» n'implique pas la reconnaissance d'une souveraineté territoriale : là, le territoire est français, et clairement français. On leur accordera des concessions ${ }^{128}$. L'indépendance est donc entendue du strict point de vue personnel : le peuple marron est reconnu en tant que tel, mais il n'a pas son propre territoire.

Le texte est d'ailleurs délibérément flou s'agissant du territoire : il reconnait l'autorité du Gran Man ndjuka sur les terres où son peuple est présent («terres où il commande», art. 2), sans préciser dans quelle colonie elles sont situées, tout en renvoyant à une zone où l'autorité française est effective («terres soumises à la domination française», art. 2). Il ne s'agit surtout pas d'en dire plus, même si, pour les Français, le Tapanahoni devant constituer le cours supérieur, les Ndjuka sont présents sur les rives françaises et néerlandaises aussi bien sur le Bas que sur le Haut Maroni.

L'article 3 pose le principe d'une stricte compétence ratione personae en matière pénale, qui va au-delà de ce que reconnaissent les traités néerlandais des années 1760 (sans parler de ceux des années 1830) : tout crime ou délit («méfait quelconque») commis par un Français ou protégé français (ressortissant français) à l'égard d'un Ndjuka relève de la compétence de la France, tandis que tout crime ou délit commis par un Ndjuka à l'égard d'un Français ou protégé français relève de la compétence ndjuka. Ce privilège de juridiction est sans doute le produit de la situation de fait existant en Guyane aussi bien pour les peuples amérindiens que pour les peuples marrons. Il n'en est pas moins à l'exact opposé des principes qui régissent les rapports entre la France et ses indigènes dans les territoires où cette catégorie existe, mais aussi des rapports de la France avec les nationaux des pays de Capitulations ${ }^{129}$ : à l'opposé de l'inégalité justifiée par la civilisation, par la supériorité du droit occidental, par la mission civilisatrice par le droit ${ }^{130}$. Ici, chacun juge ses ressortissants comme il l'entend, alors que là-bas c'est la juridiction française qui est toujours compétente.

127 C'est ce qui se passera dans le cas des Saramaka à la fin du XIXe siècle. Cf. R. PRICE, S. PRICE, Les Marrons, op. cit., pp. 56-59, p. 122, notamment l'accord de 1892 conclu par le Gran Man des Saramaka avec un ancien président du conseil général de Guyane, qui précise que «les lois françaises, protectrices de la liberté du travail et de l'égalité des hommes, n'apporteront aucune entrave à l'application du présent traité », p. 57. Sur l'immigration saramaka en Guyane pendant la ruée vers l'or, cf. M.-J. JOLIVET, La question créole, op. cit., not. pp. 153-157; M.-J. JOLIVET, « Modèle occidental et créolisation », art. cité, pp. $117-118$, not. note 10 p. 118.

$128 \mathrm{Cf}$. infra.

129 Cf. pour les Capitulations, les travaux de Jacques LAFON (Itinéraires. De l'histoire du droit à la diplomatie culturelle et à l'histoire coloniale, Paris, Publications de la Sorbonne, 2001) et, pour la justice coloniale, la série d'ouvrages Le juge et l'outre-mer (9 vol. parus depuis 2006, coll. « Dynamiques du droit », Lille, CHJ et Montpellier, Faculté de droit de l'Université Montpellier I) sous l'égide de Bernard DURAND 130 Cf. Yerri URBAN, L'indigène dans le droit colonial français (1865-1955), Paris, LGDJ, coll. «Fondation Varenne », 2011. 
Les Français pourront bien tenir, à l'occasion, un discours civilisateur vis-à-vis des Marrons ${ }^{131}$, les principes qui régissent leurs relations sont strictement opposés à l'agencement juridique correspondant à ce discours : du point de vue juridictionnel, ils sont traités sur un pied d'égalité, à la différence, par exemple, de l'Empire ottoman ou du Japon à la même époque. Chacun est compétent pour sanctionner les crimes et délits commis par ses propres ressortissants : le principe est simple, et paraît avoir été longtemps appliqué ${ }^{132}$. Ce principe implique aussi la totale autonomie des Marrons d'un point de vue «judiciaire» et d'un point de vue «législatif» : comme au Surinam, le silence implique l'autonomie.

L'entité politique ndjuka, reconnue jusqu'alors par les seuls Néerlandais est désormais reconnue de facto par les autorités françaises, et ce, de manière malgré tout beaucoup plus officielle qu'un peuple amérindien au même moment : ils vont se voir reconnaître une existence transcoloniale, intercoloniale, voire, selon les moments, quasi-internationale ${ }^{133}$. Il est inconcevable désormais que les Français remettent en cause l'autorité du Gran Man ndjuka sur ses sujets et sur ses capitaines même s'ils sont établis sur le sol français. Aujourd'hui encore, il est inconcevable que la France désigne ou fasse désigner un Gran Man ndjuka pour les seuls Ndjuka établis en Guyane française.

Enfin, par rapport aux traités conclus avec les Néerlandais, les bagnards évadés ont remplacé les esclaves marrons quant à la rémunération des captures (art. 6).

131 Le discours tenu à l'égard des Marrons en 1860-1861 est dans la tonalité de l'époque : on a vu supra que Tardy de Montravel regarde les Marrons comme des non-civilisés, au même titre que les Chinois et les Japonais. Mais il paraît assez imperméable à l'idée de mission civilisatrice. L'exposé des motifs de la "décision portant nomination d'une commission chargée de l'exploration du haut Maroni au point de vue de la science, des intérêts généraux de la colonie et de la délimitation future de la Guyane française et de la Guyane hollandaise» du 31 juillet 1861(BOGF 1861, n 438, pp. 282-283), qu'il a prise, indique qu' «il est de l'intérêt des deux colonies de multiplier leurs relations avec les populations indigènes du haut Maroni et de ses affluents supérieurs, et de les appeler à elles par la voie de la confiance et par les voies de la civilisation». Ce motif est le troisième et avant-dernier, ce qui signifie que ce n'est pas un objectif prioritaire. Sur ce discours civilisateur lié à l'expédition de 1861, beaucoup moins insistant qu'à l'égard des indigènes des colonies et surtout d'Algérie au même moment, cf. plus largement T. BELLARDIE, op. cit., pp. 61-63. 132 Cf. Ibid., p. 83ss. s'agissant d'une «plainte » du Gran Man boni auprès du gouverneur de la Guyane concernant des heurts entre Boni et orpailleurs ; M.-J. JOLIVET (op. cit., p. 154) décrit ainsi les principes « judiciaires » régissant l'immigration saramaka en Guyane dans les années 1960, admis tant par l'administration française que par les intéressés : "Dans le cas d'un litige entre deux saramaka, c'est le " capitaine » seul qui règle la question; lorsque le litige oppose un sujet guyanais à un Saramaka, fait d'ailleurs de mémoire d'homme extrêmement rare, le gendarme passe toujours par l'intermédiaire du « capitaine » pour régler le problème. »

Les Marrons pratiquent aujourd'hui une « justice à la carte » : tout en se réservant la possibilité de régler leurs affaires de manière interne, ils n'excluent pas de recourir à la justice française. Cf., s'agissant des Ndjuka, M.-J. JOLIVET, D. VERNON, « Droits, polygamie et rapports de genre en Guyane », art. cité, notamment $\S \S 38$ et 39 concernant le cas de la plainte pour viol.

133 Aujourd'hui, les Ndjuka, dont le Gran Man est au Surinam, ont aussi des capitaines reconnus officiellement en Guyane française et aux Pays-Bas. 
On ne peut réduire cette situation exceptionnelle aux simples particularités des Guyanes en termes géographiques (la forêt) ou de contrôle effectif des autorités étatiques (zone côtière contrôlée, intérieur incontrôlé où les cours d'eau sont les seules voies de communication). On pouvait trouver des populations dans des situations similaires dans le reste d'un second Empire colonial alors en cours de constitution, mais leurs membres n'en étaient pas moins indigènes. Là, est en train de se mettre en place, autour du critère de la civilisation conçue comme la soumission au droit occidental, et plus particulièrement au Code civil, une hiérarchie des peuples ${ }^{134}$ : les indigènes d'Algérie avant tout, qui ne sont ni Français ni étrangers mais régis par un droit de la nationalité qui leur est propre et rattachés au territoire dont ils sont originaires, sont considérés comme inférieurs du fait leur «arriération juridique» et de leur inaptitude supposée à être soumis au droit des civilisés, sinon de manière très lente et progressive. Du côté, du droit international public, la hiérarchie des entités politiques, qui sera systématisée vers la fin du XIXème siècle, s'organise là encore au regard du critère de la civilisation, toujours assimilée à la soumission à un droit de type occidental, au sommet de laquelle se trouvent les Etats civilisés, seuls à être pleinement sujets du droit international.

La France ne va pourtant pas traiter ces Marrons comme des «peuples mineurs», donc incapables, mais comme des peuples indépendants, certes sans territoire propre, mais en les plaçant sur un pied d'égalité avec les autorités de la colonie ("Gouverneur des Aucas», "gouverneur de la Guyane française» ; "Gran Man des Aucas», "Gran Man Français» ${ }^{135}$ ). A cela on peut donner deux raisons : le modèle persistant de la «nation libre » indienne d'une part : les pratiques à l'égard des Amérindiens ne diffèrent pas de la manière dont Français et Néerlandais les traitaient un siècle plus tôt : la liberté de migration reconnue au Ndjuka et aux Boni dans les deux colonies n'est rien d'autre, à certains égards, que la transposition aux Marrons d'un principe existant pour les peuples amérindiens ${ }^{136}$; d'autre part, l'abolition de l'esclavage de 1848 en Guyane française : elle a transformé tous les anciens esclaves en personnes pleinement capables, placées sur un strict pied d'égalité juridique avec les anciens maîtres. Pour tirer les conséquences de cette abolition vis-à-vis des peuples marrons, la France va inverser la démarche qu'elle avait eu à leur égard en 1836. Là, elle traitait avec les Pays-Bas plutôt qu'avec ces peuples qu'elle considérait comme indépendants à cause du maintient de l'esclavage, préférant reconnaître juridiquement une domination néerlandaise qu'elle considérait comme fictive ; désormais, leur indépendance est de facto reconnue et leurs rapports avec la France reposent sur des principes égalitaires : la France ne pouvait accorder moins qu'un Surinam encore esclavagiste et moins qu'à des Amérindiens auxquels elle reconnaissait en principe la liberté.

134 Pour les lignes qui suivent, cf. Y. URBAN, L'indigène dans le droit colonial français (1865-1955), op. cit., pp. 12-16 et glossaire.

135 On a vu supra que Gran Man signifie gouverneur. Ce parallélisme entre Gran Man et gouverneur paraît avoir perduré par la suite chez les Boni, au point d'inspirer le titre des souvenirs du premier préfet de la Guyane, qui a eu beaucoup de contacts avec eux, Robert VIGNON : Gran Man Baka, sans lieu d'édition, Editions Davol, 1985, not. p. 227.

136 Cf. supra. 
Dans ce contexte, la nation française fait partie des nombreuses «nations, tribus, peuplades» de la région du Maroni, à côté de celles des «Aucas, Bonis, Roucouïennes, etca» (art. 1er). Les Boni sont donc bien distinct des Français ${ }^{137}$, des Néerlandais (que l'on omet prudemment de mentionner) ou encore des Ndjuka, et la suite du texte le confirmera. Si une place parait pouvoir leur être destinée, c'est celle d'alliés («sujet français ou allié», art. 2), voire de "protégés de la France» (art. 3), mais ce sont les Amérindiens qui paraissent, en l'espèce, avant tout visés. En effet, les Français savent déjà qu'ils ne vont pas conclure d'accord écrit avec les Boni.

\section{L'ABSENCE D'ACCORD ENTRE LA FRANCE ET LES BONI}

Du côté français, on insiste sur le fait que l'esclavage est aboli en Guyane, sans doute dès avant l'expédition officielle auprès des Boni ${ }^{138}$. La position juridique officielle est très simple : le sol français affranchit l'esclave, les Boni ne sont donc plus les «esclaves des Ndjuka». Il s'agit d'une singulière réinterprétation de l'article 7 du décret d'abolition de l'esclavage de 1848 : au lieu de considérer les Boni comme des esclaves affranchis par le sol français, avec les conséquence que cela implique en terme d'état-civil et de droits politiques, au lieu de les regarder comme une collection d'individus, elle ne les voit que comme un peuple esclave affranchi par le sol français, qui devient par cela même une « tribu indépendante ». Ce faisant, la France affirme que le Tapanahoni constitue le cours supérieur du Maroni. ${ }^{139}$

Si cette position «légaliste» mais en réalité aucunement orthodoxe justifie l'absence d'accord avec les Boni, elle peut paraître surprenante au regard de l'accord avec les Ndjuka. En réalité, ce sont la puissance de ces derniers, leur position sur les rives françaises et néerlandaises sur l'ensemble du cours du Maroni (et plus à l'intérieur du Surinam), hypothèse nettement privilégiée au moment de la conclusion de la convention franco-ndjuka, la nécessité de rompre de manière assez formelle avec la reconnaissance d'une domination néerlandaise sur les Ndjuka de 1836, qui expliquent que les Français aient décidé exceptionnellement de conclure une convention écrite avec une " tribu indépendante ». S'agissant des Boni, qui sont depuis quelque temps déjà en relation indirecte avec les autorités françaises via Tollinche, et qu'on suppose en plein territoire français, la

137 Le terme «sujet français» est ici un synonyme de Français : on applique la pratique internationale consistant à nommer «citoyens» les nationaux des républiques et «sujets» les nationaux des monarchies ou des empires. Or nous sommes sous le Second Empire, tous les Français sont donc les sujets de l'Empereur Napoléon III. Cf. Y. URBAN, op. cit., p. 115.

138 C'est l'hypothèse formulée en 1862 par le posthouder auprès des Ndjuka, Kappler. S. de GROOT, op. cit., p. 80.

139 «Les Bonis, repris-je, sont, de l>aveu du gouverneur de Paramaribo, sur des terres françaises, et conséquemment aucun traité ne peut les délier vis à vis de nous, pas plus qu'ils ne peuvent être soumis à d'autres ; jusqu'à ce jour, notre gouvernement a pu paraître les négliger, paraître les oublier, mais aujourd'hui les Bonis vont recevoir tous les droits d'hommes libres et quand sur nos terres l'esclavage est solennellement aboli, qui sur nos terres pourrait prétendre l'y maintenir». Rapport du lieutenant de vaisseau Sibour, ANOM, FM, SG, GUY39, Dossier D3 (01).

Ronmy, quant à lui, affirme aux Boni qu' «ils sont libres de droit». Rapport d'un voyage fait en novembre 1860 au haut du Maroni, chez les nègres Bosch et Bonis, par M. Ronmy, ibid.. 
France ne paraît pas envisager de les traiter d'une manière différente que les peuples amérindiens présents en Guyane. Mais la manière de symboliser un lien avec la France s'avérera une question plus complexe qu'ils ne l'avaient sans doute envisagé.

Du côté néerlandais, il est par contre nécessaire de proposer un traité de paix aux Boni, l'esclavage n'étant pas encore aboli. Ce traité leur permettra par ailleurs, du côté du Surinam, d'être placés sur un pied d'égalité avec les Ndjuka ${ }^{140}$.

Puis, comme on l'a évoqué, l'expédition franco-néerlandaise annonce aux Boni leur «libération», le 18 novembre 1860, dans le village du Gran Man, Pobianski-Providence, situé sur la rive gauche du Lawa (actuelle Cottica).

Les Pays-Bas concluent alors avec les Boni le traité de paix, qui sera le dernier signé avec un peuple marron ${ }^{141}$. Après l'abolition de l'esclavage de 1863, il n'y en aura plus.

Le traité avec les Néerlandais lève toutes les restrictions à la liberté de déplacement des Boni, qui non seulement peuvent naviguer sans entrave sur le Maroni, mais peuvent s'établir partout dans la colonie du Surinam. Ils jouissent ainsi de la même liberté de circulation que les autres «Marrons pacifiés». Le texte se réfère aux nouveaux traités conclus avec les Ndjuka, Saramaka et Matawai entre 1835 et 1838 pour que leurs dispositions soient également applicables aux Boni. Comme les autres traités de paix néerlandais du XIXe siècle avec les Marrons, ce traité sera intégré à la législation de la Guyane néerlandaise ${ }^{142}$.

L'appel à l'émigration sera un échec, aussi bien du côté néerlandais que du côté français : les Boni souhaitaient pouvoir accéder à la côte, ils avaient commencé à le faire, ils en ont maintenant officiellement la possibilité. Mais ils préféreront d'abord travailler pour et avec les Français, ce qui provoquera le mécontentement des autorités coloniales néerlandaises. ${ }^{143}$

Fin 1861, une nouvelle expédition franco-néerlandaise a cette fois pour but principal de déterminer qui, du Lawa ou du Tapanahoni, est le cours supérieur du Maroni ${ }^{144}$. Un des buts accessoires est d'inciter encore les Boni à émigrer. L'échec sera identique, et comme l'on pouvait s'y attendre depuis novembre 1860, les conclusions de la commission franco-néerlandaise sont défavorables à la France : elle tranche en faveur du Lawa. La France préfèrera alors une frontière incertaine à un règlement de litige qui paraît très mal engagé. Les Boni, tout comme les Ndjuka, se trouveront alors

\section{Cf. supra.}

141 E.-R. KAMBEL, F. MacKAY, op. cit., p. 61. K. BILBY («Swearing by the Past, Swearing to the Future», p. 666) transcrit un récit d'un capitaine boni daté du 10 août 1990 relatifà la conclusion de ce traité, décrivant un rituel sweli avec le négociateur néerlandais.

Les Paramaka et les Kwinti, qui avaient préféré se tenir à l'écart, ne signeront jamais de traité de paix. Ils seront reconnus comme groupes marrons distincts par les autorités coloniales néerlandaises dans les années 1880. E.-R. KAMBEL, F. MacKAY: op. cit.; p. 61.

$142 \mathrm{Ibid} ;$ p. 65.

143 S. de GROOT: op. cit. ; pp. 78-80

Extrait d'une lettre de M. le gouverneur de la Guyane française en date du 17 janvier 1862, ANOM, FM, SG, GUY39, Dossier D3 (01).

144 T. BELLARDIE, op. cit., pp. 61-66; Gomer VIDAL, " Voyage d'exploration dans le haut Maroni, Guyanes française et hollandaise » (1861) in F. DUPUY, op. cit., pp. 231-281. 
établis en partie dans la zone située entre le Tapanahoni et le Lawa, le contesté franco-néerlandais, considéré comme neutre tant que le litige n'est pas tranché.

En 1862, le Gran Man boni Adam se rend en visite officielle à Cayenne et obtient, après avoir beaucoup insisté, un uniforme ${ }^{145}$. Mais Tardy de Montravel paraît alors abandonner ses projets de migrations boni dans l'Approuague. ${ }^{146}$

Les descriptions de la Guyane des années 1860 présentent alors les Boni comme une «peuplade complètement indépendante» ${ }^{147}$ ou comme une peuplade qui a noué avec la France des relations amicales. ${ }^{148}$

Un peuple marron établi sur la rive française du Lawa et sur le contesté franco-néerlandais, qui n'a pas conclu de traité avec la France mais entretient avec elle de bonnes relations, qui a signé un traité de paix et fait désormais partie des «Marrons pacifiés» du côté néerlandais, tels apparaissent les Boni dans les années 1860-1870. Il faudra attendre 1878 pour que les relations avec la France commencent à devenir un peu plus formalisées- mais Boni et Français devront alors se mettre d'accord quant à leur définition.

\section{B. LA CONSTRUCTION D'UN CONSENSUS FRANCO-BONI}

A partir des années 1860 , la recherche de l'or commence à se développer ${ }^{149}$. Elle finira par avoir des conséquences sur le conflit frontalier entre la France et les Pays-Bas qui, dans les années 1870, n'est toujours pas réglé. Bien qu'il empêche la présence officielle des Néerlandais sur la rive gauche du Lawa ${ }^{150}$, ces derniers ont désormais des relations commerciales privilégiées avec les Boni $^{151}$.

145 Frédéric BOUYER, La Guyane française. Notes et souvenirs d'un voyage exécuté en 1862-1863, Paris, Hachette, 1867, p. 302.

146 Il informe le ministre de heurts entre des Boni (sans doute ceux qu'il est parvenu à faire émigrer dans l'Approuague) et des Emerillons dans le Haut Approuague et conclut sa seconde lettre en insistant sur la difficulté de faire concourir les Boni aux « développement agricole et commercial de la colonie ».

Extrait d'une lettre du gouverneur de la Guyane française au ministre de la marine et des colonies du 17 janvier 1862, ANOM, FM, SG, GUY39, Dossier D3 (01).

Lettre du gouverneur de la Guyane française au ministre de la marine et des colonies du 17 juin 1862, Ibid. 147 Léon RIVIERE, La Guyane française en 1865. Aperçu géographique, historique, législatif, industriel et commercial, Cayenne, Imprimerie du Gouvernement, 1866, p. 150.

148 F. BOUYER, La Guyane française, op. cit., p. 301.

149 Sur cette ruée vers l'or, cf. M.-J. JOLIVET, op. cit., pp. 119-159; Serge MAM LAM FOUCK, Histoire de la société guyanaise. Les années cruciales. 1848-1946, Paris, éditions caribéennes, 1987. Sur le rôle des Saramaka, cf. les références supra.

150 Les Boni, établis sur le contesté et surtout sur la rive française, ne peuvent donc que s'adresser à la France en cas de difficultés touchant au territoire sur lequel ils sont établis, ce qui est renforcé par le réseau fluvial qui favorise les contacts avec la Guyane française.

H. Coudreau estime qu'en 1887, il y a 475 Boni établis en terre française et 150 sur le contesté (Henri COUDREAU, Chez nos Indiens. Quatre années dans la Guyane française (1887-1891), Paris, Hachette, 1893, p. 60).

151 En 1877, ils apportent toute leur production de bois au Surinam. T. BELLARDIE, op. cit., p. 68. 
La France prend alors conscience de la nécessité d'établir des liens plus solides avec cette 《 tribu indépendante $»^{152}$ et va construire avec elle un consensus sur leur relation. Deux personnalités boni et une personnalité créole vont tout particulièrement y contribuer : il s'agit d'Anato, Gran Man de 1876 à 1891 : il ne parle pas le français, ne sait pas écrire et s'exprime par l'intermédiaire de son interprète officiel, originaire de Sainte-Lucie, Alexandre Mondésir ${ }^{153}$. Apatou, quant à lui, en conflit avec Anato, est le guide de Jules Crevaux lors de ses explorations du bassin amazonien en 1877-1881. Le succès de Crevaux fera d'Apatou une célébrité, reçue et décorée à Paris, et un intermédiaire pour les autorités coloniales, d'autant qu'il parle bien le français.

Progressivement, Français et Boni vont considérer que leur lien est formalisé par trois éléments : l'allocation versée au Gran Man, l'investiture par la France des autorités boni et enfin la résidence du Gran Man sur le territoire français.

\section{L'ALLOCATION VERSÉE AU GRAN MAN}

Si cette allocation n'est rien d'autre qu'une réplique française de celles versées, depuis 1857, par les autorités néerlandaises aux autres Gran Man des « Marrons pacifiés » (en compensation de la suppression du tribut) ${ }^{154}$, elle n'en est pas moins le résultat d'un processus original, où le jeu entre l'oral et l'écrit produit de multiples infléchissements.

En effet, l'absence de référence à un texte écrit et daté dans le premier document décrivant les motifs de cette allocation, une lettre de 1878, laisse penser qu'elle trouve son origine dans un engagement oral : l'administration coloniale avait promis au prédécesseur d'Anato, le Gran Man Atiaba, une " gratification » de 100 francs par mois en échange de son assistance aux explorateurs du Haut-Maroni, ainsi que la garantie d'un salaire journalier à la charge de l'employeur de trois francs au maximum pour tout employé comme guide ou pagayeur. Le voyage d'exploration de Crevaux en 1877 donne l'occasion à Anato de "ratifier les promesses de son prédécesseur en aidant » cette expédition. Il reçoit en conséquence le premier terme de la " gratification ». Le commandant supérieur du Maroni, chargé de s'occuper du versement, doit s'assurer que le Gran Man Anato respecte ses engagements. ${ }^{155}$ Dès cette époque, cet accord oral « restitué » par écrit peut

152 Ibid., pp. 68-74.

153 Ibid: p. 92.

154 Cf. supra.

155 « (...) l'administration locale avait promis au prédécesseur du grand man actuel des Bonis une gratification mensuelle de cent francs payable sur les fonds du service local s>il voulait s>engager à prêter assistance aux explorateurs du Haut Maroni, notamment en leur fournissant des guides et des pagailleurs pour un salaire journalier de $3 f$. au maximum, salaire restant bien sûr à la charge des employeurs. Le Grand Man actuel a ratifié les promesses de son prédécesseur en aidant l’expédition de M. Crevaux, qui lui a directement remis en août, un premier terme de la gratification, laquelle a, dès lors, commencé à courir au profit d $>$ Anatole.

Cinq termes sont aujourd'hui échus, et l'administration vous prie de bien vouloir lui prêter votre intermédiaire pour le paiement, non seulement de la somme qui en représente le montant, mais encore des termes à venir. Elle désire en effet que l>influence de la première autorité de Saint Laurent s>exerce sur le Grand Man au profit des expéditions qui s`engageront dans le Haut-Maroni, dans l>intérêt de la science ou 
Le rattachement d'un peuple marron a la france- les boni, de la guyane neerlandaise...

URBAN, Y.

-être présenté comme une « convention », ce qui laisse croire à l'existence d'un accord écrit ${ }^{156}$. La volonté française d'améliorer les relations avec les Boni n'en est pas moins certaine en $1878^{157}$.

Une «note sur les Bonis, sous toutes réserves», non datée et non signée ${ }^{158}$, rédigée sans doute entre 1882 et $1886^{159}$ par l'administration coloniale de Cayenne, donne par la suite une tournure plus solennelle à la « sorte de convention » qui aurait été conclue en 1878 par la France et le "Grand-Man des Bonis » : le Gran Man boni tend à y devenir un équivalent français des Gran Man reconnus par les Néerlandais, qui se voit attribuer, en plus de l'allocation, un uniforme ; ses obligations deviennent plus vagues. ${ }^{160}$

du développement de lindustrie aurifère, et que les moyens d`information dont dispose le commandant supérieur servent à constater, avant la remise de la gratification que les engagements dont elle est la contrepartie soient fidèlement remplis.

M. le directeur du service pénitentiaire, consulté au sujet de la demande de concours que le service local se disposait à vous adresser dans la circonstance a exprimé le désir que l'administration intérieure obtienne votre acceptation et j'ai la confiance que vous ne nous refuseriez pas votre intervention pour maintenir les Bonis dans les dispositions favorables qu'ils manifestent actuellement en ce qui touche l'assistance à prêter aux habitants de la colonie qui s'engageront dans leur pays.

Tous les mois la gratification du Grand Man serait ordonnancée en votre nom par un mandat payable à la caisse de Saint Laurent du Maroni, et Anatole viendrait en toucher le montant en personne, soit mensuellement, soit par trimestre.

Mais il serait bien entendu que dans le cas ou vous apprendriez qu'il n'est pas fidèle à ses engagements, vous exerceriez sur les sommes ordonnancées à son profit des retenues correspondant aux manquements signalés.

Pour cette fois, M. Caillard vous remettra, conformément à l'autorisation donnée par M. le gouverneur, qui a, au surplus, l'intention de vous en entretenir, une somme de cinq cents francs représentants les termes échus (de septembre à décembre 1877, janvier 1878) depuis le paiement directement effectué en août par M. Crevaux. ”

Lettre du 9 février 1878 du directeur de l'intérieur au commandant supérieur du Maroni, ADGuyane, X352.

Cf. aussi Note du directeur de l'intérieur au directeur de l'administration pénitentiaire du 8 février 1878, AD Guyane, X388.

156 Une lettre du ministre de la marine et des colonies au gouverneur de la Guyane du 26 juillet 1878 se réfère à une convention qui vient d'être conclue avec les Boni ( « surtout depuis la convention que vous avez conclue avec eux et dont vous m'avez rendu compte par votre lettre du 2 avril dernier (...) » -J. HURAULT, M. POULIQUEN, op. cit., p. 199) .

157 Sur la base d'un arrêté réglementant la navigation et le commerce sur le fleuve Maroni daté du 7 juillet 1874 (art. 1, al. 2) (BOGF 1874, p. 362) toute embarcation sous pavillon étranger, quel que soit son tonnage, ne peut accoster sur la rive française sans autorisation du Commandant supérieur. Cette disposition est appliquée aux Boni. Ils se verront, à partir de 1878, appliquer une politique plus libérale pour les inciter à commercer avec Saint Laurent. Cf. lettre du ministre de la marine et des colonies au gouverneur de la Guyane du 26 juillet 1878, J. HURAULT, M. POULIQUEN, op. cit., p. 199, T. BELLARDIE, op. cit., p. 69 ss. Pour les autres aspects de la politique de rapprochement avec les Boni dans les années 1878-1882, ibid. 158 Note sur les Bonis, non datée et non signée, AD Guyane, X388.

159 T. BELLARDIE (op. cit., p. 76) pense qu'elle date de fin 1882-début 1883. Le document est clairement postérieur à 1881 et paraît clairement antérieur à 1887 , cf. les documents cités infra.

160 L'auteur indique que «la nation Boni a toujours été l'alliée de la France» et précise qu' «En 1878, une sorte de convention fut conclue entre la France, représentée je crois par le commandant supérieur de SaintLaurent, d'une part, et le Grand-Man des Bonis de l'autre. Il était stipulé de première part savoir $1^{\circ}$ Que

R. Fac. Dir. UFG, v. 43, p. 01-42, 2019 
Le principe du versement de l' allocation par la France au Gran Man paraît dès lors admis. Il semble que l'uniforme a, quant à lui, posé plus de difficultés. ${ }^{161}$

C'est à la faveur du réveil du conflit frontalier que les obligations d'Anato à l'égard de la France vont prendre un tour encore plus vague, rendant par là même leur lien plus abstrait. En effet, la découverte, en 1885, sur le contesté, en plein pays boni, d'un gisement d'or, rend nécessaire le règlement du litige. En 1887, suite à une lettre, peut-être apocryphe ${ }^{162}$, d' Anato, datée du 2 janvier, faisant part de conflits avec des chercheurs d'or, les autorités françaises souhaitent interdire l'exploitation de l'or sur le contesté, neutre jusqu'à ce que sa situation soit tranchée. Elles vont pour ce faire conclure une convention avec le Gran Man boni par laquelle il s'oblige à empêcher l'accès à la rive gauche du Lawa. Elles invoquent une très hypothétique convention franco-boni de $1861^{163}$.

le Grand-Man recevrait de la France une pension annuelle de 1200f; $2^{\circ} \mathrm{Qu}$ 'il lui serait donné un costume chamarré d'or à l'imitation de celui que les Hollandais donnent au Grand Man des Bosh; $3^{\circ}$ Que lorsqu'il descendrait à Saint Laurent en grand appareil (c'est à dire entouré de nombreuses pirogues et au son du tambourin), il serait reçu officiellement avec salves de coups de fusils etc... Et de seconde part savoir : Que moyennant l'exécution de ces promesses, le Gran Man favoriserait la descente et l'établissement des Bonis vers le bas du fleuve, ferait bon accueil aux voyageurs sur son territoire enfin que les prix des journées de canotages, tâches etc... seront fixés invariablement sauf recours au Gran Man lors d'inexécution de la part de ses sujets. Des documents écrits attestant cette convention existent à Saint Laurent(...) Les promesses ci-dessus n'ont été que faiblement exécutées par la France. On s'est borné à payer la pension de 1878 à 1881 et depuis cette époque elle est suspendue. Pour le costume on s'est borné à faire prendre mesure par un tailleur mais l'habit n'a même pas été commandé. Enfin, défense a été faite au commandant supérieur de Saint Laurent de recevoir le Grand Man officiellement de peur de donner de l'outrage à la colonie voisine. Le Grand-Man est littéralement furieux de la non-exécution des promesses ci-dessus et comme première mesure a mis une sorte d'interdit sur le Bas-Maroni en faisant remonter tous ses sujets.»

Note sur les Bonis, non datée et non signée, AD Guyane, X388.

Désormais, les Boni sont avant tout perçus comme ceux qui permettent d'assurer la libre circulation sur le Maroni et sur la rive française. De fait, seuls les Marrons sont capables de naviguer sur le Haut-Maroni et auront, de ce fait, un monopole de la navigation dans cette zone et un poids considérable dans la navigation sur le bas de fleuve.

161 Une lettre du Gran Man Anato au gouverneur de Cayenne du 15 octobre 1887 (AD Guyane, X388) indique au nouveau gouverneur que «pour affermir mon autorité M. Le Cardinal m'avait promis un costume officiel, cela serait important en vue de mes populations». Henri Coudreau, qui rend visite au Gran Man en septembre 1887, indique qu'il porte un costume européen (H. COUDREAU, op. cit., p. 47).

Plus largement, sur les attributs donnés par les Pays-Bas aux autorités marrons et par la France aux capitaines amérindiens à cette époque, cf. Ibid., not. pp. 22-23, p.109, p. 279.

162 T. BELLARDIE, op. cit., pp. 87-88.

163 Voici comment on invente un traité :

Le 21 janvier 1887, le gouverneur Le Cardinal demande au directeur de l'intérieur de solliciter les autorités de Saint-Laurent du Maroni pour trouver «la convention passée en 1861 avec le chef des Bonis auquel des terrains avaient été concédés dans le Haut-Maroni en représentation de certaines clauses que le Grand Man devait exécuter loyalement. La protection de nos nationaux était la principale condition de cet acte qui maintenait bien entendu la souveraineté de la France sur la rive gauche de l'Awa et celle du Maroni.» Il l'a fait chercher en vain à Cayenne (Demande du Gouverneur au Directeur de l'intérieur, 21 janvier 1887, AD Guyane, X388). 
En effet, en mars 1887, le gouverneur Le Cardinal rencontre le Gran Man Anato au village qu'a fondé il y a peu de temps Apatou, sur la rive française. Ils signent un «acte» le 14 mars 1887 , lequel sera publié ${ }^{164}$ : «Le Grand-man Anato s>engage à interdire le passage sur la rive gauche de l'Awa à tous les exploiteurs et chercheurs d'or qui viendraient s'établir sur le territoire contesté entre la France et la Hollande. Conformément au traité de 1861, le Grand-man continuera à prêter aide, secours et assistance sur la rive droite de l'Awa, concernant les terrains régulièrement concédés par la Direction de l'Intérieur à Cayenne».

Le Gran Man ne respectant pas la convention (mais avait-il les moyens de la respecter?), le gouverneur suspendra le versement de l'allocation pour l'exercice $1887^{165}$ : elle n'a plus grand chose à voir avec la rétribution de l'aide aux explorateurs qui la justifiait à l'origine. Elle est désormais un attribut du Gran Man des Boni, et sa suspension n'est plus que le signe du mécontentement des autorités françaises à son égard ${ }^{166}$.

\section{L'INVESTITURE PAR LA FRANCE DES AUTORITÉS BONI}

La réponse du commandant supérieur du Maroni, le 14 février 1887, est claire : la seule convention datant des années 1860 dont il a trouvé trace est celle conclue le 8 septembre 1860 avec les Ndjuka. Le seul document définissant les rapports avec les Boni est «une décision sans date (...) qui a trait aux engagements du Gran Man vis-à-vis de l'administration locale et vice versa» (peut-être la note non datée citée supra). De l'ensemble des décisions qu'il a pu se procurer, «il ressort que les bonis et les boschs sont indépendants, puisqu'on a traité avec eux et qu'il a été alloué une indemnité au gran man pour le concours que ses sujets prêteraient à nos nationaux». (Lettre du commandant supérieur du Maroni au directeur de l'administration pénitentiaire du 14 février 1887 et pièces jointes, AD Guyane, X388. Le commandant supérieur a également écrit au commissaire à Albina pour savoir s'il n'a pas de trace d'un document dans ses archives. Celui-ci lui répond, en mauvais français, qu'il n'a rien trouvé. «Je me rappel que les Bonis étaient soumis aux Boschs et qu'ils sont enlevés par les autorités hollandaise, mais c'est m'inconnu qu'ils sont officiellement placés sous la protection de la France.» Lettre du Commissaire hollandais Mackintosh au Commandant supérieur du Maroni Campana du 10 février 1887, AD Guyane, 388.)

Les autorités coloniales de Guyane prennent alors la décision de se prévaloir d'un traité daté de 1861, dont les termes supposés rappellent ceux de la convention franco-ndjuka de 1860 (art. 3) : le Gran Man boni devrait «aide, assistance et protection aux français, en échange de la consécration de son autonomie et de son entière indépendance vis-à-vis $d u$ chef des Bosch» (Lettre du Gouverneur de Guyane au ministre de la Marine et des Colonies, 30 mars 1887, J. HURAULT, M. POULIQUEN, op. cit., p. 201).

164 Acte intervenu entre le Gouverneur de la Guyane française et le Grand-man des Bonis pour interdire le passage sur la rive gauche de l'Awa à tous les exploiteurs et chercheurs d'or qui viendraient s'établir sur le territoire contesté entre la France et la Hollande, BOGF, 1887, n 279, p. 185.

165 Cf. lettre du Gran Man Anato au gouverneur de Cayenne du 15 octobre 1887 (AD Guyane, X388) ; Extrait du procès-verbal de la séance extraordinaire du conseil privé, J. HURAULT, M. POULIQUEN, op. cit., p. 203 ; T. BELLARDIE, op. cit., pp. 90-92.

166 La lettre de 1878 précitée décrivant les « accords » conclus avec le Gran Man est communiquée en 1888 par le commandant supérieur du Maroni au directeur de l'intérieur, mais cela ne parait pas avoir influencé les pratiques ultérieures.

Lettre du sous-directeur de la relégation, commandant supérieur du Maroni, au directeur de l'intérieur, 13 juin 1888, AD Guyane X352. 
Si la France avait reconnu de nombreuses fois des capitaines amérindiens, y compris par écrit ${ }^{167}$, elle n'avait pas investi jusqu'à présent d'autorité boni.

Le 26 juillet 1887, un arrêté du gouverneur ${ }^{168}$ dispose :

«Le Boni Apatou est nommé capitaine de la tribu des Bonis dans le haut Maroni, pour toute la circonscription du saut Hermina, sous la suzeraineté du Grand-Man Anato, et avec le consentement de ce Chef ${ }^{169}$.

Dans cette position, il devra ses bons offices a tous les Français.

Les autorités civiles et militaires fourniront, au besoin, à Apatou, aide, assistance et protection $^{170 . »}$

Une nouvelle étape est franchie ici dans la réplication des institutions régissant les « Marrons pacifiés » au Surinam.

Le texte reconnait une véritable enclave boni en territoire français ${ }^{171}$.

La pratique de l'investiture se généralisera par la suite : on sait que deux nouveaux capitaines boni seront investis par les autorités françaises le 17 juillet $1891 .{ }^{172}$

\section{LA RÉSIDENCE DU GRAN MAN SUR LE TERRITOIRE FRANÇAIS}

Ce critère est, quant à lui, est le résultat du litige frontalier.

L'évacuation du contesté par les Français et les Néerlandais en 1888, qui aboutit à la création d'un poste néerlandais sur le Lawa, ainsi que des échauffourées avec les Ndjuka à partir de 1888, intensifient la question de la puissance coloniale à laquelle se rattachent les Boni ${ }^{173}$.

167 Cf. Décision nommant le sieur Thomas Doudon, capitaine des Indiens indigènes d'Oyapock, en remplacement de son père, décédé, 16 octobre 1874, BOGF, 1874, n 676, p. 530.

168 Arrêté nommant Apatou capitaine des Bonis dans le Haut-Maroni, 26 juillet 1887, BOGF, 1887, n676, p. 652 .

169 A cause de son conflit avec Anato, Apatou avait fondé son propre village sur la rive française du Bas Maroni en 1882, en aval du premier saut du fleuve (le Saut Hermina), avec le soutien des autorités. Elle avait provoqué une scission au sein du lo Dipelu.

Cf. F. DUPUY,«Wayana et Aluku», p. 182 ; T. BELLARDIE, op. cit., pp. 78-80 et plus largement, sur Apatou, p. 74 ss.

170 On retrouve ici l'influence de l'article 3 de la convention franco-ndjuka de 1860.

171 La France avait concédé une façade de $200 \mathrm{~m}$ de rive sur une profondeur de $4 \mathrm{~km}$ de manière définitive à Apatou et à ses héritiers le 7 septembre 1885, assorti d'une prime de $15 \mathrm{~F}$ par transporté évadé et arrêté. Ibid., p. 79.

172 Ibid., p. 117 et A8.

Apatou avait sollicité, peu après sa nomination, en 1887 ou 1888, que sa fonction de capitaine soit accompagnée d'une « indemnité », apparemment sans succès. C'est pour justifier son opposition à l'attribution d'une « indemnité » que le commandant supérieur du Maroni communique la lettre relative à l' « accord de $1878 »$ au Directeur de l'intérieur.

Lettre du sous-directeur de la relégation, commandant supérieur du Maroni, au directeur de l'intérieur, 13 juin 1888, AD Guyane X352.

173 Lorsque les autorités françaises et néerlandaises décident de faire évacuer le contesté en 1888, les Boni paraissent être considérés comme des «nègres français», les Ndjuka étant considérés comme des «nègres 
Le 25 mai 1891, le tsar Alexandre III règle le conflit frontalier par une sentence arbitrale ${ }^{174}$. Il tranche, de manière prévisible, en faveur des Pays-Bas, avant tout parce que le Lawa constitue le cours supérieur du Maroni ${ }^{175}$, mais également aux motifs que « les autorités françaises de la Guyane ont maintes fois reconnu les nègres établis sur le territoire contesté comme dépendant médiatement ou immédiatement de la domination hollandaise » (ce qui résume parfaitement la convention de 1836), « et que ces autorités n'entraient en relation avec les tribus indigènes habitant ce territoire que par l'entremise et en présence du représentant des autorités hollandaises ${ }^{176}$ » (ce qui parait beaucoup plus hasardeux). Le discours néerlandais consistant à revendiquer un lien exclusif avec les peuples marrons (alors que les pratiques sont toutes autres avec les peuples amérindiens) paraît donc entériné.

hollandais», dans l'intitulé d'un ordre signé par les deux gouverneurs. Cf. Ordres adressés aux chefs des nègres français et hollandais par les Gouverneurs français et hollandais, en vue de mettre fin au passage des explorateurs et exploiteurs du Contesté situé entre les deux affluents du Maroni, l'Awa et le Tapanahoni (approuvé et signée à Cayenne et à Paramaribo, le 29 octobre 1888 et le 22 octobre 1888), AD Guyane, X388, reproduit in T. BELLARDIE, op. cit, A6.

Il ne s'agit toutefois que d'un intitulé, et la convention conclue par les gouverneurs des deux colonies le 12 novembre 1888 pour l'évacuation ne se réfère qu'aux «tribus indigènes (nègres ou indiens)», ce qui est un bon moyen d'évacuer la question de leurs dépendances respectives. («Art. IV : Les Gouvernements des deux Guyanes s'engagent à agir auprès des chefs des tribus indigènes (nègres ou indiens), pour qu'ils mettent obstacle au passage des exploiteurs sur le contesté». Convention entre la Guyane française et la Guyane hollandaise en vue de faire cesser l'exploitation du territoire contesté, situé entre les deux affluents l'Awa et le Tapanahoni, BOGF 1888, nº 492, p. 344.)

Pendant cette période précédant le règlement du litige, Anato envoie une série de lettres où, par le biais de son secrétaire-interprête Alexandre Mondésir, il marque son attachement et/ou son appartenance à la France : «Depuis un siècle mes sujets et leurs ancêtres se considèrent comme français et si la qualité officielle de naturels français leur a manqué et leur manque, je puis du moins déclarer hautement que tous les Bonis appartiennent indistinctement à la grande nation française par le coeur. (...) Notre reconnaissance pour la France, qui a toujours été notre protectrice, est héréditaire dans la tribu.»(Lettre du Gran Man Anato au gouverneur de la Guyane française, 15 novembre 1888, AD Guyane, X388), «Notre désir le plus ardent est de rester français et conserver, sinon la totalité du territoire contesté, du moins une bonne partie (...) Nous vous le répetons aujourd'hui, nous sommes Français, le territoire que nous occupons depuis plus d'un siècle est Français» (Lettre du Gran Man Anato au gouverneur de la Guyane française, J. HURAULT, M. POULIQUEN, op. cit., p. 209).

174 Recueil des sentences arbitrales, vol. XXVIII, Nations Unies, pp. 249-254.

La France avait à l'origine proposé le partage du territoire litigieux. Suite au refus des Pays-Bas, il avait été convenu de recourir à l'arbitrage du tsar. Les pouvoirs de l'arbitre étaient limités : il devait, à titre principal, déterminer qui du Lawa ou du Tapanahoni, constituait le cours supérieur du Maroni, et donc la frontière entre les deux possessions, et ne pouvait, à titre subsidiaire, fixer une autre limite que s'il ne parvenait pas, après examen du différend, à fixer comme limite une des deux rivières. Cf. Alexandre MERIGNHAC, Traité théorique et pratique de l'arbitrage international. Le rôle du droit dans le fonctionnement actuel de l'institution et dans ses destinées futures, Paris, Larose, 1895, p. 105 et plus largement, pp. 104-110.

175 «Qu'il est admis sans conteste par les deux pays intéressés que le fleuve Maroni, à partir de sa source, doit servir de limite entre leurs colonies respectives ; Que la commission mixte de 1861 a recueilli des données en faveur de la reconnaissance de l'Awa comme cours supérieur du Maroni». Recueil des sentences arbitrales, vol. XXVIII, Nations Unies, op. cit., p. 253.

176 Ibid., p. 252. C'est moi qui souligne. 
Toutefois, dans la pratique, les Néerlandais vont considérer qu'il est impossible pour un peuple marron d'être rattachés à deux puissances coloniales en même temps. En effet, après la mort d'Anato en 1891, ils tentent encore une fois de se rallier les Boni ${ }^{177}$ : discutant avec un fonctionnaire néerlandais, Apatou réclame un certain nombre de cadeaux et un drapeau néerlandais de Paramaribo. Les Néerlandais, de leur côté, espèrent que les Boni se rallieront eux-même aux Pays-Bas en promettant de fournir au Gran Man une rémunération équivalente à celle payée par les Français. Mais quand ce qui est demandé arrive de Paramaribo, les Boni le refusent.

Début 1892, un incident a lieu : les Boni de Cottica n'acceptent pas de baisser le pavillon français et de hisser le drapeau néerlandais ${ }^{178}$. Ils reçoivent l'injonction de se mettre sous le «protectorat» des Pays-Bas ou de s'établir sur la rive française. Ils envoient une délégation, comprenant le nouveau Gran Man, Ochi, à Saint-Laurent du Maroni, pour affirmer qu'ils se considèrent comme des «enfants de la France de père en fils» et demander des terres pour les Boni de Cottica. Les autorités françaises accèdent à leur demande, et Ochi s'établit sur la rive droite ${ }^{179}$.

C'est ainsi que l'application d'un arbitrage international affirmant la domination néerlandaises sur les peuples marrons amène l'un d'entre eux à manifester nettement sa volonté d'être rattaché à la France. On voit naître ici le principe selon lequel c'est le lieu de résidence du Gran Man qui détermine l'Etat auquel il se rattache, lequel sera confirmé dans les années 1960.

En effet, par la suite, une partie des Boni de Cottica regagnera le village, assurant une présence sur la rive néerlandaise. Lorsqu'en 1967, un des candidats au titre de Gran Man sera un Boni de Cottica, les autorités françaises et notamment un conseiller général qui n'était autre que l'ancien préfet, Robert Vignon, interviendront pour inciter les Boni à choisir le candidat établi sur le sol français ${ }^{180}$.

Une petite nation estimée en 1887 à 625 individus ${ }^{181}$ aura ainsi réussi à définir en partie ses rapports avec une grande, dans un contexte historique où cette dernière le refusait à toute les populations qu'elle colonisait. Et cette petite nation a aussi préféré se lier à un pays qui ne lui offrait pas de statut juridique plutôt qu'à un pays qui lui en offrait un.

Data de submissão do artigo: Novembro de 2019

Data de aceite do artigo: Março de 2020(*)

177 K. BILBY, «Divided Loyalties», art. cité, p. 151.

178 T. BELLARDIE, op. cit., pp. 119-120.

179 Ibid., pp. 120-123.

180 K. BILBY, «Divided Loyalties», art. cité, pp. 153-155; R. VIGNON, Gran Man Baka, op. cit., p. 228.

181 H. COUDREAU, op. cit., p. 60. 


\section{(*) NOTA TÉCNICA:}

Esclarecemos que, em razão do ataque de hackers a que foi submetido o conjunto de periódicos da Universidade Federal de Goiás (UFG), ao que se inclui a Revista da Faculdade de Direito da UFG (RFD/UFG), os artigos ordenados entre os números 21-30, referentes ao volume 43, embora tenham sido recebidos e aceitos em datas distintas e anteriores, dado o perecimento de suas referências, foram todos registrados com o expediente de aceite no mês de março de 2020. 